\title{
PIOTR ŚCIŚLICKI
}

Uniwersytet Jagielloński

\section{RZYMSKA GENEZA INSTYTUCJI ZAWIADOMIENIA DŁUŻNIKA \\ O PRZELEWIE WIERZYTELNOŚCI DENUNTIATIO Z C. 8,41,3 PR. A WYBRANE USTAWODAWSTWA WSPÓŁCZESNE}

\section{UWAGI WSTĘPNE}

Istotnym składnikiem konstrukcji prawnej cesji jest zawiadomienie dłużnika cedowanej wierzytelności (debitor cessus) o zmianie osoby wierzyciela. Zagadnienie jurydycznego sensu denuntiationis stanowi fragment szerszej problematyki ochrony statusu prawnego debitoris w obliczu podmiotowych przekształceń po stronie uprawnionej stosunku obligacyjnego. W relacji między cedentem a dłużnikiem przelanej wierzytelności, ważnie zawarta umowa cesyjna wywołuje skutek polegający na tym, iż cedent przestaje być wierzycielem, a podmiotem wyłącznie legitymowanym do odbioru świadczenia oraz do występowania w charakterze strony czynności prawnych dotyczących zbywanego prawa staje się cesjonariusz. W świetle ogólnych założeń większości systemów prawa obligacyjnego zwolnienie dłużnika ze zobowiązania wiąże się ze świadczeniem spełnionym do rąk podmiotu, który rzeczywiście ma w świetle prawa materialnego przymiot wierzyciela ${ }^{1}$.

\footnotetext{
${ }^{1}$ Art. 1239 code civil: „,[1] Le payement doit être fait au créancier, ou à quelqu'un ayant pouvoir de lui, ou qui soit autorisé par justice ou par la loi à recevoir
} 
Wyjątki od tej reguły nie są liczne - ilekroć dłużnik świadczy innej osobie niż materialnie uprawniony wierzyciel, zobowiązanie ulegnie umorzeniu, jeżeli accipiens legitymuje się udzielonym przez wierzyciela upoważnieniem do odbioru świadczenia, wierzyciel zatwierdzi zaistniały stan rzeczy, uznając zobowiązanie za wykonane albo też ze świadczenia skorzysta. Zasadniczo zatem, w sytuacji, gdy wierzytelność zostanie przelana, cessus może doprowadzić do umorzenia stosunku obligacyjnego, którego jest stroną, jedynie przez określone działania prawne podjęte wobec nabywcy wierzytelności - cesjonariusza. We wszystkich tych przypadkach, w których dłużnik o zaistnieniu cesji nie wie, zachodzi ryzyko, iż wobec spełnienia świadczenia do rąk swego dotychczasowego wierzyciela lub dokonania $\mathrm{z}$ nim innej czynności mającej na celu modyfikację lub zniesienie więzi obligacyjnej, świadczenie to oraz czynność pozostaną bez wpływu na jego status prawny jako podjęte wobec osoby, która w związku z przelewem nie jest już materialnie uprawniona $\mathrm{z}$ tytułu wierzytelności ${ }^{2}$. W konsekwencji debitor cessus pozostawałby w dalszym ciągu zobowiązany, cesjonariusz jako nowy wierzyciel mógłby skutecznie żądać od niego spełnienia świadczenia, a wszelkie ewentualne zarzuty oparte na fak-

pour lui. [2] Le payement fait à celui qui n'aurait pas pouvoir de recevoir pour le créancier, est valable, si celui-ci le ratifie, ou s'il en a profité". - code civil - deuxième édition rédigée avec le concours de G. GouBEAUX - P. BIHR - X. HENRY, Dalloz 1997-1998 (cyt. dalej c.c.); § 362 BGB: „(1) Das Schuldverhältnis erlischt, wenn die geschuldete Leistung an den Gläubiger bewirkt wird. (2) Wird an einen Dritten zum Zwecke der Erfüllung geleistet, so finden die Vorschriften des § 185 Anwendung”. - Bürgerliches Gesetzbuch, Beck-Texte, 2001 (cyt. dalej BGB); art. 204 polskiego kodeksu zobowiązań z 1933 r.: „Świadczenie do rąk osoby, do odbioru nieumocowanej, zwalnia dłużnika, o ile wierzyciel je potwierdził lub z niego skorzystał". - Dz. U. z 1933 r. Nr 82, poz. 598 (cyt. dalej k.z.); art. 452 polskiego kodeksu cywilnego z 1964 r.: „Jeżeli świadczenie zostało spełnione do rąk osoby nieuprawnionej do jego przyjęcia, a przyjęcie świadczenia nie zostało potwierdzone przez wierzyciela, dłużnik jest zwolniony w takim zakresie, w jakim wierzyciel ze świadczenia skorzystał ...”. - Dz. U. z 1964 r. Nr 16, poz. 93 (cyt. dalej k.c.).

${ }^{2}$ K. ZAWADA, Ochrona dtużnika przy przelewie wierzytelności, «ZN UJ Prace Prawnicze» 142 (1992), s. 9. 
cie uprzedniej zapłaty do rąk cedenta lub też powołujące okoliczność ograniczenia lub innej modyfikacji zakresu obowiązków dłużnika przez czynność prawną ze zbywcą wierzytelności, pozbawione byłyby jakiegokolwiek znaczenia prawnego. Jeżeli dany system prawa cywilnego ma być oparty na regule ochrony interesów podmiotu działającego w dobrej wierze, w usprawiedliwionym acz błędnym przekonaniu o istnieniu określonych stanów faktycznych lub prawnych, ryzyko podwójnego świadczenia nie może być akceptowane. Niezbędne jest zatem uwzględnienie w jurydycznym schemacie instytucji przelewu mechanizmu znoszącego negatywne konsekwencje prawnej irrelewancji zachowań dłużnika, które to zachowania intencjonalnie, w jego usprawiedliwionym subiektywnym odczuciu powinny były wywołać skutek zwalniający. Priorytetową rolę w tym zakresie spełnia właśnie zawiadomienie debitoris o przelewie. Zamyka ono przedział czasowy, w ramach którego dłużnik może uniknąć negatywnych skutków prawnych swych poczynań, które w świetle zaistniałej post cessionem nowej sytuacji cechuje nieadekwatność $\mathrm{z}$ punktu widzenia podniesionego do rangi zasady wymagania, by podmiot uprawniony in obligatione występował zarazem in solutione. Czyniąc przedmiotem rozważań denuntiationem, nie sposób pominąć także i tych okoliczności ze sfery kontekstu faktycznego, które $\mathrm{w}$ prawem wyznaczonych granicach są $\mathrm{z}$ nią zrównane pod względem skutków prawnych i stanowią tym samym jej ekwiwalenty. Są to okoliczności różnej natury, wśród których napotykamy zarówno zachodzące w obiektywnej rzeczywistości czynności uczestników obrotu, jak również stany świadomości tych uczestników, zwłaszcza wiedzę o zaistnieniu określonych faktów i o kształtującej się w ich następstwie sytuacji prawnej. Prawo rzymskie, zwłaszcza okresu klasycznego, cechował daleko posunięty brak elastyczności w zakresie norm regulujących zagadnienia określane we współczesnej cywilistyce mianem podmiotowych przekształceń stosunków obligacyjnych. Rzymska obligatio była strukturą statyczną, której płaszczyzna podmiotowa od chwili kreacji więzi zobowiązaniowej aż po kres bytu stosunku prawnego pozostawała bez zmian. Obrót prawami majątkowymi innymi niż rzeczowe - niezbędny ze względów gospodarczych - torował sobie drogę pośrednio, a jego prawnym nośnikiem stawały się 
instytucje, które pod względem właściwego swego przeznaczenia $\mathrm{i}$ istoty odbiegały od konstrukcji znanej legislacjom nowożytnym jako cesja wierzytelności, a będącej szczególnym przypadkiem translatywnego nabycia prawa pod tytułem szczególnym³ ${ }^{3}$ Zagadnienie, czy dorobek iurisconsultorum objął w późniejszych stadiach swej ewolucji również ideę sukcesyjnej cessionis, jest w romanistyce sporne ${ }^{4}$. Niemniej, nie budzi wątpliwości, iż rozważania rzymskiej jurysprudencji objęły swym zakresem ów specyficzny układ interesów, kształtujący się w sferze faktycznego kontekstu stosunków między zbywcą wierzytelności, jej nabywcą oraz podmiotem $z$ tytułu tej wierzytelności zobowiązanym. Bez względu na kontrowersje w przedmiocie charakteru rzymskiej cesji bezsporne jest, iż pojawiające się w płaszczyźnie konfrontacji wspomnianych interesów problemy z kryterium ich należytego wyważenia były rzymskim prawnikom nieobce, a prawnicza refleksja dotycząca tej materii w spuściźnie iurisprudentium znalazła swe odzwierciedlenie. Dowodzi tego poświęcony kwestii cesyjnej denuntiationis fragment Kodeksu Justyniana - C. 8,41,3 pr.

Zasadniczym przedmiotem niniejszych rozważań będzie zagadnienie refleksów wspomnianego unormowania w wybranych współczesnych ustawodawstwach kontynentalnych: francuskim, włoskim, austriackim, niemieckim, szwajcarskim i polskim, a nadto w konstrukcji podstawowych rozwiązań, przyjmowanych w omawianym zakresie na gruncie prawa kontraktowego Wielkiej Brytanii i Stanów Zjednoczonych ${ }^{5}$. Punkt wyjścia stanowić będzie krótka prezen-

${ }^{3}$ K. LuIG, Zur Geschichte der Zessionslehre, Köln 1966, s. 3.

${ }^{4}$ F. Zoll, Pandekta czyli nauka rzymskiego prawa prywatnego, III: Zobowiąania, Kraków 1910, s. 20-21; W. RozWADowsKI, Przelew wierzytelności w prawie rzymskim, Poznań 1969, s. 198-199; K. LUIG, op. cit., s. 6.

${ }^{5}$ Problematykę cesji wierzytelności regulują: we Francji - art. 1689-1701 code civil z 1804 r., we Włoszech - art. 1260-1267 codice civile z 1942 r. (cyt. dalej cod. civ.), w Austrii - $\$$ 1392-1399 Allgemeines bürgerliches Gesetzbuch z 1811 r., (cyt. dalej ABGB), w Niemczech - §§ 398-413 BGB z 1896, w Szwajcarii - art. 164174 code fédéral des obligations z 1911 r. (cyt. dalej c.o.). Polski kodeks zobowiązań z 1933 r. normował przelew w art. 168-176. Na gruncie obecnie obowiązującego polskiego kodeksu cywilnego z 1964 r. przelewowi poświęcone są art. 509-517. 
tacja historycznej ewolucji quasi-cesji rzymskiej, zwłaszcza ostatniego stadium rozwoju tej instytucji, ze szczególnym uwzględnieniem kontrowersji wokół jej prawnego charakteru. W dalszym toku wywodów nastąpi zarysowanie podstawowych koncepcji w przedmiocie pierwotnej rationem legis unormowania z C. 8,41,3 pr., odpowiednio do reprezentowanych $\mathrm{w}$ romanistyce stanowisk co do sukcesyjności rozwiniętego przelewu rzymskiego. Ustalenie zakresu potencjalnych interpretacji wymienionego fragmentu źródłowego na tle różnych koncepcji cesji rzymskiej pozwala na pełniejsze rozważenie jego inspirującej roli dla obecnie obowiązujących systemów prawa cywilnego. Na ich kształcie zaważyła przecież nie tylko właściwa materia i treść prawa rzymskiego, ale również obraz tego prawa w oczach tych, którzy je badali. Sposób rozumienia i interpretacji prawnego dziedzictwa Rzymian przez romanistów, często niejednorodny, odzwierciedlił się także we współczesnym prawie cywilnym, nierzadko znajdując wyraz w wielowariantowości modelowych rozwiązań określonych dogmatycznych zagadnień szczegółowych.

II. OSOBISTY CHARAKTER ZOBOWIĄZAŃ W PRAWIE RZYMSKIM. PALIATYWY PRZELEWU I ICH EWOLUCJA

Klasyczne prawo rzymskie, stojące na gruncie zasady osobistego charakteru więzi obligacyjnej, nie znało instytucji cesji w dzisiejszym znaczeniu tego pojęcia, jako czynności prawnej wywołującej bezpośrednio skutek sukcesyjny - skutek, który ujmowany $\mathrm{z}$ perspektywy przedmiotowej polega na przejściu wierzytelności $\mathrm{z}$ majątku cedenta do majątku cesjonariusza, w perspektywie podmiotowej zaś wyraża się wstąpieniem nowego wierzyciela w miejsce dotychczasowego, przy zachowaniu tożsamości i identyczności stosunku obligacyjnego, z którego wynika objęte transakcją pra-

W USA zasadnicze założenia, na których oparte zostały regulacje stanowe w przedmiocie przelewu, są zawarte w Restatement Second of Contracts, częściowo zaś także w Uniform Commercial Code (cyt. dalej UCC). 
wo ${ }^{6}$. Więź zobowiązaniowa miała tak dalece osobisty charakter, iż mimo istnienia ekonomicznej potrzeby zapewnienia swobodnego obrotu uprawnieniami o charakterze obligacyjnym, nie dopuszczano możliwości odseparowania wierzytelności od osoby wierzyciela i przeniesienia jej na inny podmiot ${ }^{7}$. Niedopuszczalność transmisji najpełniej wyrażona została przez Gaiusa, który opisując w komentarzu drugim Institutionum różne sposoby nabywania praw rzeczowych wyraźnie wyłącza $\mathrm{z}$ zakresu zastosowania mechanizmów sukcesji syngularnej podmiotowe prawa obligacyjne i to niezależnie od sposobu kreacji stosunku zobowiązaniowego w danym przypadku${ }^{8}$.

${ }^{6}$ M. KASER, Das römische Privatrecht, $\mathrm{I}^{2}$, München 1971, s. 652-653; R. SOHM L. MITTEIS - L. WENGER, Instytucje, historia i system rzymskiego prawa prywatnego, Warszawa 1925, s. 455-457; R. MONIER, Manuel de droit romain. Les obligations, Paris 1954, s. 261-262; P.F. GIRARD, Manuel élémentaire de droit romain, Paris 1918, s. 743-744; P. OURLIAC - J. DE MALAFOSSE, Droit romain et ancien droit français, Paris 1957, s. 219-220; H. MazeAud - L. MazeAud - J. Mazeaud, Leçons de droit civil, II, Paris 1969, s. 1059: „L'obligation a deux aspects. D'une part, elle est un lien personnel entre deux ou plusieurs personnes, qui détermine leurs rapports réciproques. D'autre part, elle est un élément du patrimoine, élément actif dans le patrimoine de créancier, élément passif dans celui du debiteur; une créance est ..., un élément de richesse, une fraction du capital".

${ }^{7}$ R. Monier, op. cit., s. 262; G.F. Puchta, Cession, [w:] Kleine civilistische Schriften, Leipzig 1851, s. 456-457; R. TAUBENSCHLAG, Rzymskie prawo prywatne ${ }^{2}$, Warszawa 1969, s. 217-219; W. RozWADowski, Prawo rzymskie. Zarys wykładu wraz $z$ wyborem źródet, Warszawa 1991, s. 155-157.

${ }^{8}$ G. 2,38-39: Obligationes quoquo modo contractae nihil eorum recipiunt: nam quod mihi ab aliquo debetur, si id velim tibi deberi, nullo eorum modo, quibus res corporales ad alium transferuntur, id efficere possum; sed opus est, ut iubente me tu ab eo stipuleris; quae res efficit, ut a me liberetur et incipiat tibi teneri: quae dicitur novatio obligationis. Sine hac vero novatione non poteris tuo nomine agere, sed debes ex persona mea quasi cognitor aut procurator meus experiri; por. też G. MAY, Éléments de droit romain, Paris 1892, s. 404; C.R. vON CZYHLARZ, Lehrbuch der Institutionen des römischen Rechtes, Prag-Wien-Leipzig 1893, s. 207-208; W.D. GEHRICH, Kognitur und Prokurator in rem suam als Zessionsformen des klassischen römischen Rechts, Göttingen 1963, s. 3; G. AstuTI, s.v. Cessione, [w:] Enciclopedia del diritto, VI, Milano 1960, s. 806-807. 
Sprzeczność między wymaganiami rozwijającego się obrotu gospodarczego a tradycyjną tezą o nierozerwalnym związku między podmiotem a przedmiotem obligacji doprowadziła do ukształtowania się pewnych zastępczych form przenoszenia wierzytelności paliatywów cesji'.

Stosowane w omawianym zakresie instytucje, a w szczególności nowacja ze zmianą wierzyciela (novatio inter novas personas) ${ }^{10}$ oraz zastępstwo procesowe in rem suam, cechowały się tego rodzaju właściwościami, że zbędne było stosowanie jakichkolwiek dodatkowych gwarancji statusu prawnego dłużnika zbywanej wierzytelności. Odnowienie jako surogat przelewu w praktyce najczęściej występowało we wspólnej konfiguracji z rzymskim przekazem (delegatio), przy czym chodzi tu o delegację czynną celem zobowiązania (delegatio nominis obligandi causa $)^{11}$. Quasi-cedent, występując w charakterze przekazującego (delegans), upoważniał w drodze iussum swego dotychczasowego dłużnika, aby ten jako przekazany (delegatus) zobowiązał się stypulacyjnie do świadczenia na rzecz nabywcy wierzytelności (quasi-cesjonariusza), mającego w tym układzie status prawny odbiorcy przekazu (delegatarius) - do świadczenia, które dotychczas był dłużny przekazującemu ${ }^{12}$. W konsekwencji wspomnianej stipulationis stosunek prawny wiążący dotychczasowego wierzyciela $\mathrm{z}$ dłużnikiem podlegał umorzeniu przez nowację i ustępował miejsca nowej więzi obligacyjnej, konsty-

${ }^{9}$ G.H. MAIER, Zur Geschichte der Zession, [w:] Festschrift E. Rabel, II, Tübingen 1954, s. 205-207; K. LUIG, op. cit., s. 3-9.

${ }^{10}$ G. 2,38-39: ... sed opus est, ut iubente me tu ab eo stipuleris; quae res efficit, ut a me liberetur et incipiat tibi teneri: quae dicitur novatio obligationis. Sine hac vero novatione non poteris tuo nomine agere, sed debes ex persona mea quasi cognitor aut procurator meus experiri; por. też F. Zoll, Pandekta, cit., s. 20.

${ }^{11}$ W. LITEWSKI, Rzymskie prawo prywatne ${ }^{4}$, Warszawa 1999, s. 252-253; W. ENDEMANN, Der Begriff der Delegatio im klassischen römischen Recht, Marburg 1959, s. 8; R. Taubenschlag, op. cit., s. 217-219; W. Rozwadowski, Prawo rzymskie, cit., s. $155-157$.

${ }^{12}$ C.R. von CZYhlarz, op. cit., s. 208. 
tuującej się między dłużnikiem a wskazaną przez wierzyciela osobą trzecią ${ }^{13}$. Zachodząca tu novatio była pod względem swych skutków ekonomicznych praktycznie równoznaczna ze współczesnym przelewem wierzytelności ${ }^{14}, \mathrm{z}$ prawnego punktu widzenia jednak, gdy pominąć aspekt koherencji funkcjonalnej, obie instytucje nie mają ze sobą nic wspólnego. W przypadku odnowienia brak bowiem zachowania ciągłości stosunku zobowiązaniowego, z którego wynika będąca przedmiotem obrotu wierzytelność. O ile w przypadku przelewu cedent i cesjonariusz są stronami tej samej obligationis, przekazujący jako ekonomiczny zbywca wierzytelności oraz delegatariusz jako jej nabywca są podmiotami cedowanego prawa na podstawie dwóch różnych stosunków prawnych. Nie sposób mówić zatem o jurydycznej tożsamości obu wierzytelności ${ }^{15}$.

Quasi-cesja, urzeczywistniana według schematu delegacji nowacyjnej, zakładała jako konieczną przesłankę swej skuteczności aktywne współdziałanie dłużnika w formie złożenia przyrzeczenia stypulacyjnego in favorem nabywcy wierzytelności ${ }^{16}$. Przez samo swe bierne zachowanie mógł więc debitor cessus uniemożliwić całą operację, a ewentualność dokonania przelewu wierzytelności bez jego

${ }^{13}$ J. ZiELONACKI, Pandekta czyli wykład prawa prywatnego rzymskiego, Kraków 1871, s. 74-75; M. KASER, op. cit., s. 653; W. ENDEMANN, op. cit., s. 8-9, 23-24.

${ }^{14}$ C.R. vON CzyHlarz, op. cit., s. 208. Biorąc pod uwagę, iż nowacja zobowiązania, w przeciwieństwie do cesji, pociąga wygaśnięcie zabezpieczeń wierzytelności, również w samej płaszczyźnie ekonomicznej nie da się bez zastrzeżeń utrzymać tezy o gospodarczej tożsamości przelewu i nowacji ze zmianą wierzyciela. Wierzytelność zabezpieczona osobiście czy rzeczowo przedstawia ekonomicznie wyższą wartość niż taka, której realizacja nie jest gwarantowana żadnym prawem akcesoryjnym.

${ }^{15}$ Por. D. 7,1,25,2 (Ulp. 18 ad Sab.): ... quamvis non soleat stipulatio semel cui quaesita ad alium transire nisi ad heredem vel adrogatorem ...; por. też R. MoNIER, op. cit., s. 262; P.F. GIRARD, op. cit., s. 744.

${ }^{16}$ E. CUQ, Manuel des institutions juridiques des Romains, Paris 1928, s. 638; R. Monier, op. cit., s. 262; C.R. von CzYHLARZ, op. cit., s. 208; M. KASER, op. cit., s. 653; W. OsUCHOWSKI, Rzymskie prawo prywatne, Warszawa 1981, s. 402; K. LuIG, op. cit., s. 3 . 
wiedzy i narażenia go przez to na ryzyko spełnienia świadczenia do rąk już nie uprawnionego cedenta lub dokonania $\mathrm{z}$ wymienionym innej czynności prawnej celem modyfikacji zakresu swoich obowiązków nie wchodziła w ogóle w rachubę.

Obok nowacji służyły urzeczywistnieniu obrotu wierzytelnościami, bez naruszania tezy o stricte osobistej naturze więzi obligacyjnej, pewne formy zastępstwa procesowego. Wierzyciel zamierzający zbyć przysługujące mu przeciwko dłużnikowi prawo ustanawiał nabywcę pełnomocnikiem procesowym, który następnie w imieniu swego mocodawcy, posługując się cudzą skargą procesową, pozywał dłużnika o świadczenie należne domino litis ${ }^{17}$. Na podstawie dodatkowego porozumienia między mocodawcą a zastępcą, ten ostatni mógł zatrzymać ściągnięte od dłużnika świadczenie ${ }^{18}$. To dodatkowe porozumienie przekształcało instytucję typowo procesową w instrument służący wywołaniu określonych efektów materialnoprawnych. Differentiam specificam owej szczególnej formy pełnomocnictwa stanowiło działanie zastępcy procesowego w cudzym imieniu, na swoją rzecz i w swoim interesie (in rem suam ) $^{19}$. Z natury więzi procesowej jako stosunku reprezentacji wynikała podstawowa wada przedstawicielstwa jako namiastki przelewu wierzytelności. Ustanowienie nabywcy prawa kognitorem lub prokuratorem nie pociągało żadnych zmian w obrębie węzła jurydycznego między zbywcą a dłużnikiem. Cedent-mocodawca, aż do chwili contestationis $\mathrm{w}$ relacji nabywca - dłużnik, sam pozostawał wierzycielem i, co za tym idzie, mógł osobiście dokonywać czynności prawnych rzutujących na istnienie lub kształt stosunku obligacyjnego, z którego wynikała zbywana wierzytelnośćc ${ }^{20}$. W szczególności mógł osobiście dokonać z dłużnikiem contestationem, przyjąć od dłużnika świad-

${ }^{17}$ G.F. PuCHTA, op. cit., s. 459-460; J. ZIELONACKI, op. cit., s. 63-64.

${ }^{18}$ W. RozWADOWSKI, Przelew, cit., s. 20-21.

${ }^{19}$ G. MAY, op. cit., s. 404; E. CUQ, op. cit., s. 638-639; K. KOLAŃCZYK, Prawo rzymskie ${ }^{5}$, Warszawa 2001, s. 449; K. LUIG, op. cit., s. 3-4.

${ }^{20}$ W. LITEWSKI, op. cit., s. 252-253; W. OSUCHOWSKI, op. cit., s. 403; P.F. GIRARD, op. cit., s. 746; G.F. PuCHTA, op. cit., s. 482; K. KOLAŃCZYK, op. cit., s. 449. 
czenie ze skutkiem zwalniającym dla tego ostatniego, umorzyć zobowiązanie przez nowację albo zawrzeć cum debitore skuteczne wobec cesjonariusza pactum de non petendo ${ }^{21}$. Sytuację zastępcy in rem suam osłabiało dodatkowo przysługujące domino litis uprawnienie do odwołania pełnomocnika ${ }^{22}$, a nadto zasada, w myśl której pełnomocnictwo wygasało $z$ chwilą śmierci mocodawcy ${ }^{23}$.

Niedoskonałość stosowanej tu konstrukcji prawnej jako paliatywu dzisiejszego przelewu stwarzała korzystną sytuację dla dłużnika cedowanej wierzytelności. Jak łatwo spostrzec, tak ukształtowany mechanizm obrotu prawami nie naruszał statusu prawnego debitoris. Skoro bowiem ustanowienie przez wierzyciela pełnomocnika procesowego nie stanowiło źródła jakiejkolwiek istotnej zmiany w ramach materialnej więzi obligacyjnej, dłużnik mógł w dalszym ciągu skutecznie zwolnić się ze zobowiązania przez świadczenie do rąk zbywcy prawa, bądź też dokonać z nim innej czynności prawnej, skierowanej na zmodyfikowanie kształtu stosunku obligacyjnego, którego był stroną ${ }^{24}$. Cesjonariusz był z punktu widzenia dłużnika zwykłym pełnomocnikiem procesowym, a przymiot in rem suam dotyczył wyłącznie płaszczyzny materialnych stosunków między zbywcą a nabywcą wierzytelności. Jedynie w tej płaszczyźnie skutkowało zawarte między cedentem a cesjonariuszem porozumienie, mocą którego ten ostatni mógł zachować dla siebie to, co jako pełnomocnik procesowy miał wyegzekwować od dłużnika. Układ ten stanowił sui generis materialnoprawną causam dla czysto procesowych czynności, jakimi były substitutio cognitoris, czy też constitutio procuratoris, a nabywca wierzytelności opierał swe działanie w płaszczyźnie procesowej na takich samych zasadach, jak każdy

${ }^{21}$ G.F. PUCHTA, op. cit., s. 482; W.D. GEHRICH, op. cit., s. 18;

${ }^{22}$ Por. D. 3,3,16 (Paul. 8 ad ed.): Ante litem contestatam libera potestas est vel mutandi procuratoris vel ipsi domino iudicium accipiendi; por. też P. OURLIAC J. DE MALAFOSSE, op. cit., s. 219-220; M. KASER, op. cit., s. 653.

${ }^{23}$ Frag. Vat. 333: Multis enim casibus ignorantibus nobis mandatum solvi potest vel morte ...; por. też W. RozWADowski, Przelew, cit., s. 96.

${ }_{2.1}$ W. Rozwadowski, Przelew, cit., s. 86-87; G.F. PuchTa, op. cit., s. 482. 
inny pełnomocnik procesowy. Wobec tego, jeśli quasi-cedent przyjął świadczenie, nabywca nie był uprawniony do żądania zapłaty od dłużnika, a swych należności mógł dochodzić jedynie od zbywcy, na podstawie łączącego ich stosunku materialnoprawnego.

Gdy z chwilą utwierdzenia sporu (litis contestatio) wstępowal quasi-cesjonariusz $\mathrm{w}$ pozycję prawną domini litis ${ }^{25}$ i zbywca wierzytelności ostatecznie tracił możliwość oddziaływania na wierzytelność, nie było ryzyka spełnienia świadczenia na rzecz nielegitymowanego już cedenta. Dłużnik w każdym przypadku wiedział o zmianie podmiotu uprawnionego, gdyż jego obecność jako pozwanego (adversarius) stanowiła prawną przesłankę contestationis ${ }^{26}$.

Podobnie nie stwarzała zagrożeń dla podmiotu zobowiązanego sytuacja, gdy cedent dokonał ponownego przelewu tej samej wierzytelności na inną osobę. Jeżeli dalszy nabywca uprzedził pierwszego w ściągnięciu należności od dłużnika, zobowiązanie wygasało i nie było możliwości ponownego pozwania debitoris o to samo świadczenie.

Nietrudno zauważyć, że podstawowy mankament opisanego sposobu obrotu wierzytelnościami stanowiła niepewność statusu prawnego nabywcy prawa w fazie postępowania bezpośrednio poprzedzającej litem contestatam ${ }^{27}$. Samo ustanowienie zastępcy in rem suam nie pozbawiało mocodawcy możliwości osobistego wpływania na więź prawną łączącą go z dłużnikiem ze skutkiem dla zastępcy. Wierzyciel po zbyciu przysługującego mu prawa pozostawał nadal uprawniony z tytułu wierzytelności i mógł usque ad contestationem w stosunkach między nabywcą a dłużnikiem realizować wszelkie

${ }^{25}$ D. 49,1,4,5 (Macer 1 de appel.): Si procurator, qui iudicio interfuit, victus sit, an ipse quoque per procuratorem appellare possit videamus, quia constat procuratorem alium procuratorem facere non posse. sed meminisse oportet, quod procurator lite contestata dominus litis efficitur: et ideo et per procuratorem appellare potest.

${ }^{26}$ W. OsUCHOWsKI, op. cit., s. 135; K. KUPISZEWSKI, Litis contestatio. Uwagi na marginesie pracy: Günter Jahr, Litis contestatio. Streitbezeugung und Prozessbegründung im Legisaktionen- und Formularverfahren, «CPH» 15.1 (1963), s. 258-259.

${ }^{27}$ W. RozWadowski, Przelew, cit., s. 221; K. LUIG, op. cit., s. 4. 
przysługujące mu z tytułu wierzytelności uprawnienia, faktycznie pozbawiając $w$ ten sposób beneficjenta przelewu - cesjonariusza możliwości korzystania z nabytego aktywu. Niewątpliwie naruszał w ten sposób swe zobowiązania wobec nabywcy, jak choćby te, które wypływały $z$ materialnoprawnego stosunku leżącego u podstaw przeniesienia wierzytelności i ponosił z tego tytułu odpowiedzialność kontraktową, co wszakże nie zmienia faktu, iż tak ukształtowany mechanizm nie był konstrukcją w pełni adekwatną $\mathrm{z}$ punktu widzenia przypisywanych mu funkcji ${ }^{28}$. Rozwój systemu zmierzał zatem ku stabilizacji i zabezpieczeniu sytuacji prawnej cesjonariusza, ku ograniczeniu władztwa, jakie poniekąd wbrew logice miał cedent względem zbytej wierzytelności. Ewolucja przebiegała w tym zakresie wielotorowo, nie dotykając zrazu aspektów strukturalnych. Przykładowo, nie miały większego znaczenia dla samej konstrukcji prawnej mechanizmu towarzyszące stosunkowi podstawowemu stipulationes, przez które zbywca dodatkowo zobowiązywał się do pati w zakresie przysługujących mu z tytułu zbytej wierzytelności uprawnieńn ${ }^{29}$. Przełomowe znaczenie miał reskrypt Antoninusa Piusa ${ }^{30}$, który przyznał nabywcy spadku (emptor hereditatis) możliwość pozwania dłużnika spadkowego (debitor hereditarius), a także skutecznego dokonania $\mathrm{z}$ nim innych czynności prawnych dotyczących wierzytelności spadkowych nie w cudzym, lecz we własnym imieniu (suo nomine), na mocy przyznanej w tym celu actionis utilis $^{31}$. Odtąd przedmiotowy zakres zastosowania actionis suo nomine ulegał stopniowemu rozszerzaniu na przypadki sukcesji

${ }^{28}$ G.F. PUCHTA, op. cit., s. 482-483.

${ }^{29}$ M. Kaser, op. cit., s. 653-654; W. Rozwadowski, Przelew, cit., s. 97; TenŻE, Sprzedaż pojedynczej wierzytelności $w$ rzymskim prawie okresu republiki. Analiza D. 44,4,4,6, «CPH» 19.2 (1967), s. 84-85.

${ }^{30}$ Antoninus Pius - Titus Aelius Caesar Antoninus (138-161).

${ }^{31}$ Wiedzę o treści wspomnianej konstytucji czerpiemy z wypowiedzi Ulpiana D. 2,14,16 pr. (Ulp. 4 ad ed.): Si cum emptore hereditatis pactum sit factum et venditor hereditatis petat, doli exceptio nocet. nam ex quo rescriptum est a divo Pio utiles actiones emptori hereditatis dandas, merito adversus venditorem hereditatis exceptione doli debitor hereditarius uti potest; por. też R. SOHM - L. MITTEIS - L. WENGER, 
pod tytułem szczególnym. Gordian III ${ }^{32}$, reskryptem z 242 r. n.e., przyznał możliwość posłużenia się actione utile w sytuacji bezdziedzicznej śmierci cedenta ante litem contestatam ${ }^{33}$. Konstytucja cesarzy Waleriana i Galliena $a^{34}$ z 260 r. n.e. przyznała omawiany przywilej nabywcy wierzytelności wchodzącej w skład posagu ${ }^{35}$. W $294 \mathrm{r}$. n.e. Dioklecjan ${ }^{36}$ objął zakresem zastosowania skargi przypadki przekazania wierzytelności tytułem dationis in solutum ${ }^{37}$ oraz nabycia nomen $\mathrm{w}$ drodze zapisu ${ }^{38}$. Nabywca praw donandi causa natomiast mógł korzystać z actionis suo nomine począwszy od czasów Justyniana ${ }^{39}$.

op. cit., s. 457-458; R. MONIER, op. cit., s. 263-264; E. CUQ, op. cit., s. 639-640; M. KASER, op. cit., s. 654; W. OsUCHOWSKI, op. cit., s. 403.

${ }^{32}$ Gordian III - Marcus Antonius Gordianus (238-244).

${ }^{33}$ C. 4,10,1: Data certae pecuniae quantitate ei cuius meministi in vicem debiti actiones tibi adversus debitorem, pro quo solvisti, dicis esse mandatas et, antequam eo nomine litem contestareris, sine herede creditorem fati munus implesse proponis. quae si ita sunt, utilis actio tibi competit; por. też W. RozWADOWskI, Przelew, cit., s. 169-170; E. CuQ, op. cit., s. 639.

${ }^{34}$ Walerian - Publius Licinius Valerianus (253-260); Gallien - Publius Licinius Egnatius Gallienus (253-268).

${ }^{35}$ C. 4,10,2: Nominibus in dotem datis, quamvis nec delegatio praecesserit nec litis contestatio subsecuta sit, utilem tamen marito actionem ad similitudinem eius qui nomen emerit dari oportere saepe rescriptum est; por. też P.F. GIRARD, op. cit., s. 747.

${ }^{36}$ Dioklecjan - Gaius Aurelius Valerius Diocletianus (284-305).

${ }^{37}$ C. 4,15,5: In solutum nomine dato non aliter nisi mandatis actionibus ex persona sui debitoris adversus eius debitores creditor experiri potest. suo autem nomine utili actione recte utetur; por. też W. RoZWADOWsKI, Przelew, cit., s. 172.

${ }^{38}$ C. 6,37,18: Ex legato nominis, actionibus ab his qui successerunt non mandatis, directas quidem actiones legatarius habere non potest, utilibus autem suo nomine experietur.

${ }^{39} \mathrm{C} .8,53,33$ pr.: Illam subtilem observationem amputamus, per quam donationis titulo cessiones actionum accipientes non aliter eas suis transmittere heredibus poterant, nisi litem ex his contestati essent vel ius contestationis divino rescripto meruissent. nam sicut venditionis titulo cessas actiones etiam ante litis contestationem ad heredes transmitti permittitur, simili modo et donatas ad eos transferri volumus, licet nulla contestatio vel facta vel petita sit. 
III. FUNKCJA NOTYFIKACJI Z C. 8, 41, 3 PR. NA TLE POGLĄDÓW W PRZEDMIOCIE KONSTRUKCJI PRAWNEJ PRZELEWU RZYMSKIEGO. ZAWIADOMIENIE DŁUŻNIKA JAKO PRZESŁANKA SKUTECZNOŚCI CESJI. UNORMOWANIE NOTYFIKACJI W PRAWIE FRANCUSKIM I WŁOSKIM

Istotnym elementem kształtującej się konstrukcji prawnej stała się denuntiatio, czyli zawiadomienie dłużnika o zaistniałej w stosunkach między cedentem a cesjonariuszem umowie przelewu oraz zrównane $\mathrm{z}$ nią $\mathrm{w}$ skutkach uznanie przelewu przez dłużnika per facta concludentia - przez częściowe świadczenie do rąk cesjonariusza. Wiedzę o tej oryginalnie rzymskiej instytucji ${ }^{40}$ czerpiemy z wydanej w 239 r. n.e. konstytucji Gordiana III:

C. 8,41,3 pr.: Si delegatio non est interposita debitoris tui ac propterea actiones apud te remanserunt, quamvis creditori tuo adversus eum solutionis causa mandaveris actiones, tamen, antequam lis contestetur vel aliquid ex debito accipiat vel debitori tuo denuntiaverit, exigere a debitore tuo debitam quantitatem non vetaris et eo modo tui creditoris exactionem contra eum inhibere ${ }^{41}$.

Wynika $\mathrm{z}$ tego, iż w razie zbycia wierzytelności i ustanowienia cesjonariusza zastępcą in rem suam, cedent tracił możliwość osobistego pozwania dłużnika nie tylko wówczas, gdy w stosunkach między nabywcą a zobowiązanym dochodziła do skutku litis contestatio, ale również z chwilą zawiadomienia dłużnika o przelewie (... debitori tuo denuntiaverit ...), a nadto, gdy dłużnik choćby częściowo spełnił świadczenie na rzecz cesjonariusza (... aliquid ex debito accipiat ...).

Nie sposób odpowiedzieć in abstracto i bez czynienia pewnych założeń na pytanie, z myślą o czyim bezpieczeństwie prawnym została wprowadzona instytucja denuntiationis i czy jej ówczesna ratio

\footnotetext{
${ }^{40}$ K. LUIG, op. cit., s. 118.

${ }^{41}$ P.F. GIRARD, op. cit., s. 748; www.gmu.edu.
} 
legis odpowiadała tej, jaką ma ona we współczesnych systemach prawa cywilnego. Przypisanie notyfikacji z C. 8,41,3 pr. określonego uzasadnienia prawnego wiąże się bowiem bezpośrednio $\mathrm{z}$ założeniami przyjętymi w przedmiocie roli, jaką dla konstrukcji przelewu rzymskiego miała przyznana cesjonariuszowi actio utilis suo nomine. W tej ostatniej kwestii brak natomiast w literaturze jednomyślności. Zgodnie z najmniej radykalnym stanowiskiem reforma polegająca na przyznaniu cesjonariuszowi wymienionej skargi nie miała w gruncie rzeczy istotnego znaczenia, a w szczególności nie zmieniała podstawowych zasad, na których opierał się obrót wierzytelnościami, w tym reguły osobistego charakteru obligationis ${ }^{42}$. Nie doszło tu zatem do wykształcenia cesji w dzisiejszym znaczeniu tego pojęcia, jako formy sukcesji syngularnej. Cesjonariusz uzyskiwał zaledwie uprawnienie do odbioru z rąk dłużnika świadczenia spełnianego w wykonaniu cudzej wierzytelności (exercitium actionis, Ausübung der Forderung) ${ }^{43}$. Cedent mimo zawarcia umowy cesji nadal pozostawał wierzycielem, zachowywał actionem directam i mógł $\mathrm{z}$ jej pomocą przedsiębrać $\mathrm{w}$ swych stosunkach $\mathrm{z}$ dłużnikiem wszelkie czynności prawne, do których jako wierzyciel był uprawniony, w szczególności osobiście pozwać dłużnika, zawrzeć z nim pactum de non petendo, ponownie sprzedać tę samą wierzytelność itp $^{44}$. Ograniczenia swobody cedenta nadal miały charakter wyłącznie obligacyjny. Jeżeli więc wykonując swe uprawnienia pozbawił cesjonariusza możliwości realizacji nabytej wierzytelności, ponosił względem niego odpowiedzialność opartą na materialnoprawnym stosunku, stanowiącym podstawę przelewu, a niekiedy również szczególną odpowiedzialność z tytułu zawartej z cesjonariuszem

${ }^{42}$ G.F. Puchta, op. cit., s. 482; H. Dernburg, Pandekten, Berlin 1886, s. $129-$ 130; W. OsUCHOWSKI, op. cit., s. 403; K. LUIG, op. cit., s. 47.

${ }^{43}$ K. LUIG, op. cit., s. 51: „Der Zessionar erhalte somit als procurator in rem suam die Befugnis zu verlangen, daß $\mathrm{ihm}$ ein fremdes Forderungsrecht erfüllt werde; er erhalte die 'Ausübung' der Forderung".

${ }^{44}$ W. OsuChOWsKI, op. cit., s. 403; K. KOLAŃCZYK, op. cit., s. 450; P.F. GIRARD, op. cit., s. 748. 
dodatkowo stypulacji cesyjnejas. Nie zmieniało to jednak faktu, iż z cesją nie wiązał się skutek rozporządzający. Podobnie jak poprzednio, dopiero litis contestatio między nabywcą a dłużnikiem kładła ostatecznie kres władztwu cedenta nad zbytą wierzytelnością, a to w związku z nowacją stosunku obligacyjnego (novatio necessaria), nabyciem przez cesjonariusza statusu domini litis oraz następującym już na jego rzecz zasądzeniem. Znaczenie actionis utilis miałoby się w tym układzie przejawiać jedynie w umocowaniu cesjonariusza do działania suo, a nie alieno nomine, a więc także wówczas, gdy brak wyraźnego mandatu ze strony mocodawcy.

Przyjęcie tej opcji interpretacyjnej prowadzi do wniosku, iż w takim układzie denuntiatio miała za cel przede wszystkim ochronę statusu prawnego cesjonariusza, służąc mu jako dodatkowy instrument, z którego pomocą mógł on jeszcze przed stwierdzeniem sporu wyłączyć cedenta od wpływu na wierzytelność, a zarazem wykluczyć możliwość zwolnienia się dłużnika ze zobowiązania przez świadczenie cedentowi oraz pozbawić skuteczności wszelką inną czynność prawną przedsięwziętą między zobowiązanym a zbywcą ${ }^{46}$.

Skoro skutki przelewu nadal ograniczają się do płaszczyzny stosunków między cedentem i cesjonariuszem, cesja nie ma skutku rozporządzającego, wierzytelność pozostaje przy zbywcy, a cesjonariusz uzyskuje jedynie możliwość jej realizacji, oznacza to dla dłużnika brak ryzyka spełnienia świadczenia do rąk osoby nieuprawnionej. Jeżeli bowiem dłużnik o przelewie nie wiedział i płacił cedentowi, zwalniał się ze zobowiązania, gdyż accipiens mimo zawarcia umowy przelewu nadal zachowywał swe materialne uprawnienia z tytułu wierzytelności. Ilekroć zaś cessus o przelewie wiedział, mógł zwolnić się ze zobowiązania zarówno świadcząc materialnie legitymowanemu cedentowi, jak i do rąk cesjonariusza, mającego wszak status pełnomocnika wierzyciela. Wprowadzenie zatem instytucji denuntiationis nie tylko nie służyło bezpieczeństwu prawne-

\footnotetext{
${ }^{45}$ M. Kaser, op. cit., s. 653-654; W. Rozwadowski, Przelew, cit., s. 97.

${ }^{46} \mathrm{~J}$. RzodKowsKI, Pandekta. Zobowiazania - część ogólna i szczegótowa, Lwów 1935 , s. $45-46$.
} 
mu debitoris, lecz wręcz w pewnym sensie pogarszało jego sytuację, ograniczając zakres pozostających w jego dyspozycji sposobów uwolnienia się od zobowiązania. Jeżeli bowiem cessus otrzymał odpowiadające warunkom C. 8,41,3 pr., a zatem pochodzące od cesjonariusza ${ }^{47}$ zawiadomienie o cesji, jedyną osobą legitymowaną do odbioru świadczenia oraz do bycia stroną dotyczących wierzytelności przelanej czynności pozostawał cesjonariusz.

Identyczne znaczenie przypisać należy denuncjacji w świetle koncepcji, według której wyposażony w actionem utilem cesjonariusz $\mathrm{z}$ chwilą przelewu wstępował $\mathrm{w}$ istniejący stosunek zobowiązaniowy kumulatywnie, obok dotychczasowego wierzyciela, który zachowywał swoje prawa ${ }^{48}$. Powstająca sytuacja korealności czynnej sprawiała, iż w interesie cesjonariusza, podobnie jak w poprzednio opisanym przypadku, leżało jak najszybsze wyłączenie współuprawnionego wierzyciela od wpływu na zbytą wierzytelność oraz zamknięcie dłużnikowi drogi do zwolnienia się ze zobowiązania przez świadczenie do rąk cedenta. Tym właśnie celom, a nie ochronie debitoris służyłoby w tym ujęciu unormowanie C. 8,41,3 pr.

Stanowisko, zgodnie z którym opisane reformy, a w szczególności przyznanie cesjonariuszowi actionis utilis suo nomine, doprowadziły do wykształcenia $w$ prawie rzymskim cesji wierzytelności o charakterze sukcesyjnym, występuje w dwóch wariantach, w zależności od przypisywanego notyfikacji znaczenia dla perfekcji umowy przelewu ${ }^{49}$.

Punkt wyjścia rekonstrukcji pierwszego ze wzmiankowanych wariantów stanowi założenie, iż po przełamaniu zasady nomina ossibus

\footnotetext{
${ }^{47}$ Zasadniczo, pochodzące od cedenta zawiadomienie dłużnika o przelewie nie stanowi przesłanki z C. 8,41,3 - K. LUIG, op. cit., s. 51. Wbrew literalnemu brzmieniu C. $8,41,3$ reprezentowany był między innymi pogląd, iż denuntiatio, o której mowa w będącym przedmiotem analizy fragmencie mogła pochodzić również od cedenta - F. EISELE, Die 'Actio utilis' des Cessionars, Freiburg 1887, s. 50.

${ }^{48}$ H. Dernburg, op. cit., s. 130; P.F. Girard, op. cit., s. 748; K. KolańczyK, op. cit., s. 449; W. RozWadowski, Przelew, cit., s. 196-199; W. OsuchowsKI, op. cit., s. 403.
}

${ }^{49}$ W. RozWadowski, Przelew, cit., s. 198-199. 
inhaerent $t^{50} \mathrm{i}$ dopuszczeniu swobodnego obrotu wierzytelnościami jako rzeczami niezmysłowymi (res incorporales, quae tangi non possunt, quae in iure consistunt $)^{\text {s1 }}$, jego zasady kształtowały się na wzór reguł normujących obrót rebus corporalibus. Do skutecznego prawnie przeniesienia własności rzeczy zmysłowej nie wystarczał sam konsens jako zgodna wola stron obejmująca animum dominii transferendi et accipiendi - niezbędne było również istnienie iustae causae traditionis, a nade wszystko faktyczne wręczenie rzeczy nabywcy, czyli tradycja (traditio). Niektórzy badacze przyjmują zatem konsekwentnie, że podobne elementy musiały wystąpić, aby możliwe było przeniesienie wierzytelności ${ }^{i 2}$. Z uwagi na właściwość przedmiotu transakcji, rolę traditionis jako fizycznego wydania rem nabywcy pełniła notyfikacja ${ }^{\text {s3 }}$. Nabycie wierzytelności przez cesjonariusza nie następowało zatem $\mathrm{w}$ tym ujęciu z chwilą zawarcia umowy przelewu, lecz dopiero $\mathrm{z}$ chwilą zawładnięcia wierzytelnością, symbolicznego objęcia jej w posiadanie przez nabywcę (Besitzergreifung), w drodze zawiadomienia debitorem cessum o zmianie osoby wierzyciela ${ }^{54}$. Denuntiatio urasta w świetle opisanej koncepcji do roli przesłanki skuteczności prawnej cesji, a nadto właśnie jako cessionis condicio iuris chroni interes dłużnika. W przeciwieństwie bowiem do dwóch poprzednio przedstawionych koncepcji, według których rzymski przelew nie miał charakteru sukcesyjnego, $w$ tym przypadku będąca przedmiotem transakcji wierzytelność przestaje stanowić aktyw cedenta, wchodząc do majątku cesjonariusza. Zachodzi więc ryzyko, iż cessus nie wiedząc o zmianie

${ }^{50}$ W. RoZWADOWSKI, Przelew, cit., s. 215.

${ }^{51}$ G. 2,12-14: Quaedam praeterea res corporales sunt, quaedam incorporales. Corporales hae sunt, quae tangi possunt, velut fundus, homo, vestis, aurum, argentum et denique aliae res innumerabiles. Incorporales sunt quae tangi non possunt, qualia sunt ea, quae in iure consistunt, sicut hereditas, ususfructus, obligationes quoquo modo contractae ...; D. 50,16,23 (Ulp. 14 ad ed.): Rei appellatione et causae et iura continentur.

${ }_{52}$ J. RzodKowsKI, op. cit., s. 47; G. MAY, op. cit., s. 404; K. LUIG, op. cit., s. 126.

${ }_{53}$ J. RzodKowsKI, op. cit., s. 47; G. MAY, op. cit., s. 404; K. LUIG, op. cit., s. 126.

${ }^{{ }^{4}}$ H. Derniurg, op. cit., s. 130-131. 
osoby wierzyciela spełni świadczenie do rąk cedenta, które to świadczenie jako spełnione do rąk osoby nie będącej już wierzycielem nie wywoła skutku zwalniającego, a cesjonariusz będzie mógł skutecznie dochodzić od dłużnika uiszczenia należności do jego rąk. Ryzyko to nie powstaje w sytuacji, gdy powiadomienie dłużnika o fakcie zaistnienia przelewu oraz dowodzące wiedzy dłużnika o zmianie podmiotu uprawnionego częściowe świadczenie do rąk nowego wierzyciela podniesione zostaną do rangi alternatywnych przesłanek skuteczności cesji.

$\mathrm{Na}$ płaszczyźnie legislacyjnej opisany sposób rozumienia sensu denuntiationis znalazł odzwierciedlenie w prawie francuskim oraz włoskim.

Prawo francuskie recypowało rzymskie unormowanie z C. 8,41,3 pr., traktując denuncjację (signification) oraz przyjęcie przelewu przez dłużnika (acceptation) jako warunkujące skuteczność transakcji condiciones iuris $^{55}$. W okresie prawa feudalnego, gdy wielu umowom przypisywano charakter aktów realnych sygnifikacja i akceptacja były w obrocie wierzytelnościami tym, czym traditio przy czynnościach prawnych mających za przedmiot res corporales mobiles - rzeczową przesłanką ważności aktu, z której zaistnieniem cesjonariusz podlegał wwiązaniu w wierzytelnośćct. Przeważało zarazem przekonanie, iż sama wiedza dłużnika o przelewie, pochodząca $z$ innych źródeł, nie była wystarczająca dla perfekcji cesji.

Zmierzająca ku upowszechnieniu zasady konsensualności ewolucja koncepcji czynności prawnej powodowała stopniową eliminację elementów realnych, w tym tradycji oraz jej ekwiwalentów, jako przesłanek skuteczności prawnej aktu. Wbrew tej generalnej tendencji sygnifikacja i akceptacja zostały recypowane przez nowożyt-

${ }^{55}$ Art. 108 coutume'u paryskiego stanowił: „le simple transport ne saisit pas, il faut signifier le transport à la partie et lui en bailler copie" - cyt. za J. GHESTIN C. Jamin - M. BilliaU, Traité de droit civil. Les effets du contrat, Paris 1994, s. 449; treść powołanego przepisu upowszechniła się pod postacią maksymy: Simple transport ne saisit point - P. OURLIAC - J. DE MALAFOSSE, op. cit., s. 223-225.

${ }^{56}$ A. WeIll - F. TerRé, Droit civil. Les obligations, Paris 1986, s. 940. 
ne ustawodawstwo francuskie, znajdując swą sedem materiae w art. 1690 c.c. ${ }^{57}$. Dlatego niekiedy spotkać można pogląd, iż powołany przepis stanowi jedynie reminiscencję dawnego stanu prawnego, który bez głębszego uzasadnienia został mechanicznie powielony przez twórców kodeksu. Jest to jednak mało prawdopodobne wobec faktu, iż cywilne prawo francuskie w dobie kodyfikacji cechowała zdecydowana i od dłuższego czasu utrzymująca się przewaga zasady konsensualności kontraktów. Skoro odrzucono traditionem jako warunek nabycia rem corporalem, to tym bardziej zrezygnowanoby $\mathrm{z}$ przesłanki quasi-tradycji w obrocie rzeczami niezmysłowymi, gdyby za jej utrzymaniem nie przemawiały racje funkcjonalne ${ }^{58}$.

Problematyka perfekcji cesji francuskiej jest w świetle art. 1690 c.c. bardziej złożona. Denuntiatio i uznanie przelewu przez dłużnika zyskały tu szczególny status i w zasadzie nie warunkują ważności cesji w ogóle, a jedynie jej skuteczność w płaszczyźnie stosunków zewnętrznych (opposabilité). Przepisy art. 1689 c.c. ${ }^{59}$ i art. 1690 c.c. stwarzają konieczność prowadzenia analizy skutków prawnych umowy przelewu w dwóch płaszczyznach: płaszczyźnie stosunków wewnętrznych, między cedentem a cesjonariuszem (inter partes) oraz płaszczyźnie stosunków zewnętrznych, odzwierciedlającej oddziaływanie przelewu na sytuację prawną osób trzecich, to jest wszystkich tych podmiotów, które nie są stronami umowy cesyjnej (erga omnes). Dla wywołania skutków prawnych w pierwszej $\mathrm{z}$ wymienionych płaszczyzn wystarcza samo zawarcie umowy; nadanie przelewowi pełnej skuteczności, ukonstytuowanie stanu prawnego, z którym liczyć muszą się wszyscy uczestnicy obrotu, wymaga zaistnienia jednej z przesłanek $\mathrm{z}$ art. 1690 c.c., a mianowicie sygnifikacji lub akceptacji przelewu.

\footnotetext{
${ }^{57}$ Art. 1690 c.c.: „Le cessionaire n'est saisie à l'égard des tiers que par la signification du transport faite au debiteur. Néanmoins le cessionnaire peut être également saisi par l'acceptation du transport faite par le debiteur dans un acte authentique".

${ }^{58} \mathrm{~J}$. HorowsKI, Cesja wedtug prawa cywilnego obowiazujacego w Matopolsce $z$ uwzględnieniem przepisów prawa obowiazującego w innych dzielnicach Polski, jak i nowego projektu polskiego kodeksu zobowiazań, Kraków 1933, s. 86-87.

${ }^{59}$ Art. 1689 c.c.: „Dans le transport d'une créance, d'un droit ou d'une action sur un tiers, la délivrance s'opère entre le cédant et le cessionnaire par la remise du titre".
} 
W stosunkach wewnętrznych między stronami umowy przelewu, cedentem i cesjonariuszem, przejście wierzytelności następuje solo consensu, a więc już w momencie złożenia zgodnych oświadczeń woli ${ }^{60}$, jakkolwiek stylizacja art. 1689 c.c., normującego zagadnienie perfekcji cesji w tej płaszczyźnie, może sugerować charakter realny czynności. Powołany przepis stanowi bowiem, że przeniesienie wierzytelności, prawa lub skargi między zbywcą a nabywcą urzeczywistnia się przez oddanie tytułu (par la remise du titre). Prima facie mogłoby się więc wydawać, że poza konsensem, istotną przesłanką skuteczności cesji inter partes jest oddanie nabywcy tytułu, to jest pisemnego dokumentu stwierdzającego wierzytelność. Doktryna francuska jednak zapatruje się na tę kwestię inaczej, przypisując umowie przelewu w stosunkach wewnętrznych w pełni konsensualny charakter ${ }^{61}$. Argument systemowy wskazuje, iż cesja jest w świetle code civil szczególnym przypadkiem umowy sprzedaży i co za tym idzie podlega dyspozycji art. 1583 c.c. ${ }^{62}, \mathrm{z}$ którego to przepisu wyinika, iż sprzedaż jest zupełna między stronami, a kupujący nabywa własność względem sprzedawcy z chwilą, gdy umówiono się o rzecz i cenę. Oddanie tytułu pojmować należy, wobec tego, nie w kategoriach elementu realnego warunkującego ważność czynności, lecz jako stanowiące obowiązek cedenta wydanie rzeczy sprzedanej nabywcy ${ }^{63}$, o którym to obowiązku mowa w art. 1603 c.c. ${ }^{64}$

${ }^{60}$ H. Mazeaud - L. Mazeaud - J. Mazeaud, Leçons de droit civil, II, Paris 1969, s. 1077; M. PLANIOL - G. RIPERT, Traité pratique de droit civil français, VII: Obligations, Paris 1954, s. 495-496.

${ }^{61}$ H. Mazeaud - L. Mazeaud - J. Mazeaud, op. cit., s. 1077; A. Weill F. Terré, op. cit., s. 943; A. Colin - H. CAPITANT, Cours élémentaire de droit civil français, II, Paris 1932, s. 354-355.

${ }^{62}$ Art. 1583 c.c.: „Elle est parfaite entre les parties, et la propriété est acquise de droit à l'acheteur à l'égard du vendeur, dès qu'on est convenu de la chose et du prix, quoique la chose n'ait pas encore été livrée ni le prix payé".

${ }^{63}$ H. Mazeaud - L. Mazeaud - J. Mazeaud, op. cit., s. 1077.

${ }^{64}$ Art. 1603 c.c.: „Il a deux obligations principales, celle de délivrer et celle de garantir la chose qu'il vend". 
Odmiennie przedstawia się zagadnienie skuteczności przelewu w stosunkach zewnętrznych, wobec osób trzecich (à l'égard des tiers). Stosownie do art. 1690 c.c. umowa przelewu staje się skuteczna względem trzecich, gdy dłużnikowi zostanie doręczone zawiadomienie o przelewie (signification) lub dłużnik dokona przyjęcia cesji w odpowiednim akcie urzędowym (acceptation).

Francuska konstrukcja dwustopniowej skuteczności przelewu stwarza znaczne komplikacje zarówno w teorii jak i praktyce. Już sam teoretyczny opis modelu, którego istotę stanowi rozwarstwienie sfer oddziaływania umowy cesyjnej, rodzi trudności. W literaturze francuskiej spotkać można dwa zasadnicze sposoby wykładni art. 1690 c.c. Część autorów przyjmuje fikcję, że są dwa momenty przejścia wierzytelności z majątku zbywcy do majątku cesjonariusza, w zależności od tego, czy przedmiotem analizy są stosunki wewnętrzne czy też zewnętrzne. $Z$ punktu widzenia relacji prawnej między kontrahentami - zbywcą i nabywcą prawa, wierzytelność przechodzi już w chwili zawarcia umowy, z punktu widzenia podmiotów nie będących uczestnikami transakcji, skutek rozporządzający następuje materialnie dopiero po dopełnieniu formalności związanych $\mathrm{z}$ zawiadomieniem dłużnika. Inni rezygnują z posługiwania się fikcją prawną, przyjmując, iż już w chwili zawarcia umowy wierzytelność staje się aktywem majątku nabywcy; do chwili zawiadomienia dłużnika lub zaistnienia ekwiwalentu denuntiationis w postaci uznania cesji przez zobowiązanego, umowa przelewu jest nie w pełni skuteczna (opposable) w tym sensie, że nie można się w tym okresie powoływać na fakt przejścia prawa wobec osób trzecich, w tym także erga debitorem ${ }^{65}$. Przedstawione stanowiska mają znaczenie przede wszystkim teoretyczne; z praktycznego punktu widzenia, różnica między nimi jest niewielka. W świetle obu zaprezentowanych ujęć, dłużnik będzie obowiązany zaspokoić roszczenia nabywcy dopiero po zaistnieniu jednej z przesłanek $\mathrm{z}$ art. 1690 c.c. Podobnie dopiero wówczas, wierzyciele cesjonariusza, prowadzący

${ }^{65}$ J. Horowski, op. cit., s. 85; H. MaZEAUd - L. MAZEAUd - J. MAZEAUd, op. cit., s. 1078. 
egzekucję z jego majątku, będą mogli dochodzić zaspokojenia z nabytego przezeń prawa.

Recypując wzorzec rzymski dokonano pewnych jego modyfikacji. O ile więc denuntiatio z C. 8,41,3 pr. miała charakter ustny, sygnifikacja, o której mowa w art. 1690 c.c. najczęściej dokonywana jest w odpowiednim dokumencie urzędowym (par acte d'huissier). Podobnie sformalizowano „przyjęcie” przelewu przez dłużnika. Codex Iustinianus mówi w tym zakresie o częściowym świadczeniu spełnionym przez dłużnika do rąk cesjonariusza: aliquid ex debito accipiat, a więc obiektywnym zachowaniu debitoris, ujawniającym per facta concludentia jego wiedzę o zaistniałym przelewie. Uznanie cesji (acceptation) z art. 1690 c.c. wymaga natomiast, co do zasady, ujęcia oświadczenia woli w formę aktu urzędowego (acte authentique).

Tak zmodyfikowanej instytucji notyfikacji przypisuje się przede wszystkim funkcję ochrony debitoris cessus przed ryzykiem podwójnego świadczenia oraz nadto rolę czynnika zapewniającego odpowiedni stopień jawności i publiczności przelewu wobec nie biorących udziału w transakcji uczestników obrotu ${ }^{66}$. Gwarancyjny charakter art. 1690 c.c. dla statusu prawnego dłużnika nie opiera się na zasadzie ochrony jego dobrej wiary przez usankcjonowanie świadczenia spełnionego $\mathrm{w}$ nieświadomości przelewu do rąk nieuprawnionego już cedenta, lecz na zasadzie pozbawienia przelewu, o którym dłużnik nie został powiadomiony w trybie art. 1690 c.c. lub którego w sposób opisany w tym przepisie nie zaakceptował, skuteczności prawnej względem niego (opposabilité) ${ }^{67}$. Z rozwiązaniem tym harmonizuje stanowiący już wszakże pewne superfluum art. 1691 c.c. ${ }^{68}$, zgodnie z którym dopóki nie zostaną spełnione przesłanki skuteczności cesji erga omnes, dłużnik zwalnia się ze zobowiązania

${ }^{66}$ A. Colin - H. CAPITANT, op. cit., s. 355-356; K. ZawadA, Umowa przelewu wierzytelności, Kraków 1990, s. 66-70.

${ }^{67}$ K. ZAWADA, Umowa, cit., s. 67-70.

${ }^{68}$ Art. 1691 c.c.: „Si, avant que le cédant ou le cessionnaire eût signifié le transport au débiteur, celui-ci avait payé le cédant, il sera valablement libéré". 
świadcząc do rąk cedenta. Brak formalnej sygnifikacji lub akceptacji sprawia, iż z punktu widzenia dłużnika cedent w dalszym ciągu jest wierzycielem i świadczenie spełnione na jego rzecz ma skutek zwalniający jako spełnione do rąk osoby legitymowanej, zatem w zgodzie z ogólną zasadą, a nie w drodze wyjątku od niej. Wzgląd na uniknięcie trudności dowodowych przy ustalaniu, czy cessus został o przelewie powiadomiony, a także podyktowana potrzebą zapewnienia bezpieczeństwa obrotu konieczność odpowiedniego uwierzytelnienia daty, począwszy od której skuteczność cesji wykracza poza sferę dwustronnych stosunków między zbywcą a nabywcą, stały się przyczyną nadania cesyjnej denuncjacji oraz jej ekwiwalentowi charakteru ściśle formalnego.

W świetle art. 1690 i 1691 c.c. faktyczna, nieformalna wiedza dłużnika o przelewie pozbawiona jest znaczenia prawnego, co prowadzi do sui generis paradoksu, polegającego na tym, iż nawet, gdy cessus wie o zmianie osoby wierzyciela, ale nie zaistniała żadna spośród przesłanek z art. 1690 c.c., świadczenie cesjonariuszowi nie zwolni debitoris ze zobowiązania. Sama świadomość przelewu po stronie dłużnika nie wystarczy by uznać, że przelew jest względem niego skuteczny ${ }^{69}$.

Przedstawiona konstrukcja stwarza niezwykle korzystną sytuację dla dłużnika, eliminując całkowicie niebezpieczeństwo podwójnego świadczenia. Z uwagi na kwalifikowany charakter przesłanek skuteczności cesji w płaszczyźnie zewnętrznej, z których zaistnieniem w sposób nieunikniony wiąże się pozyskanie przez dłużnika wiedzy o zmianie wierzyciela, cessus praktycznie nie może się mylić co do tego, kto jest materialnie uprawniony z tytułu wierzytelności i komu w związku z tym powinien świadczyć, by umorzyć zobowiązanie. Konsekwencją pozbawienia niekwalifikowanej wiedzy debitoris o przelewie prawnej relewancji jest podważenie bezpieczeństwa prawnego cesjonariusza, który ponosi ryzyko utraty nabytego prawa wskutek działań dłużnika, w tym również wskutek czynności podejmowanych w złej wierze. Literalnie interpretowane unormowa-

${ }^{69}$ J. Ghestin - C. Jamin - M. Billiau, op. cit., s. 449. 
nia $\mathrm{z}$ art. 1690 i 1691 c.c. prowadzity niejednokrotnie do rozstrzygnięć sprzecznych z poczuciem sprawiedliwości, co sprawiło, że postulat ochrony statusu nabywcy stał się istotnym czynnikiem kształtującym linię orzeczniczą $\mathrm{w}$ sprawach $\mathrm{z}$ zakresu podmiotowych przekształceń stosunków obligacyjnych ${ }^{70}$.

Bardzo podobne do francuskiego rozwiązanie, polegające na wyróżnianiu płaszczyzn skuteczności umowy przelewu w aspekcie podmiotowym oraz na przypisaniu denuncjacji znaczenia przesłanki skuteczności rozporządzenia cesyjnego w relacjach zewnętrznych, przewiduje prawo włoskie. Art. 1264 cod. civ. stanowi, iż cesja jest skuteczna względem dłużnika, jeżeli zostanie przez niego przyjęta (accettata) lub jest mu notyfikowana (notificata) $)^{71}$. Ten sam przepis w zdaniu drugim wprowadza jednak unormowanie w sposób istotny odbiegające od modelu francuskiego, viz. stanowi, iż mimo braku notyfikacji, dłużnik, który spełnia świadczenie in favorem cedenta nie będzie wolny od zobowiązania, jeżeli cesjonariusz udowodni, że cessus $\mathrm{w}$ chwili świadczenia wiedział o zaistnieniu przelewu. W przeciwieństwie zatem do rozwiązania francuskiego, nie występuje tu ryzyko zwolnienia ze zobowiązania dłużnika, który wiedząc o cesji, w złej wierze wykorzystuje brak notyfikacji i płaci dług do rąk cedenta.

\section{DENUNTIATIO JAKO CZYNNIK WYŁĄCZAJĄCY DOBRĄ WIARE DŁUŻNIKA. UNORMOWANIE NOTYFIKACJI W PRAWIE AUSTRIAC- KIM, NIEMIECKIM, SZWAJCARSKIM I POLSKIM}

Niektórzy romaniści, przyjmujący, iż w momencie przyznania cesjonariuszowi możliwości posłużenia się actione utile suo nomine doszło w prawie rzymskim do przełamania dogmatu o osobistym charakterze obligacji i do wykształcenia cesji wierzytelności jako

\footnotetext{
${ }^{70}$ K. ZaWadA, Umowa, cit., s. 66-70; H. MaZEAUd - L. MAZEAUd - J. MaZEAUD, op. cit., s. 1079; M. PLANIOL - G. RIPERT, op. cit., s. 502-506; A. WEILL F. TERrÉ, op. cit., s. 945; J. GHESTIN - C. JAMIN - M. BilliaU, op. cit., s. 448-450.

${ }^{71}$ Art. 1264 cod. civ.: „Efficacia della cessione riguardo al debitore ceduto. [1] La cessione ha effetto nei confronti del debitore ceduto quando questi l'ha accettata
} 
formy sukcesji syngularnej, zakładają, iż skutek rozporządzający, czyli przejście wierzytelności z majątku zbywcy do majątku cesjonariusza, następowało już w chwili zawarcia umowy kauzalnej stanowiącej podstawę przelewu, a nie dopiero w momencie zawiadomienia dłużnika ${ }^{72}$. Przyjęcie tej koncepcji narzuca odmienną od wyżej przedstawionej interpretację unormowania C. 8,41,3 pr., zgodnie $\mathrm{Z}$ którą notyfikacja oraz jej ekwiwalent w postaci częściowego świadczenia na rzecz cesjonariusza nie stanowiły przesłanki skuteczności przelewu, lecz jedynie czynnik wyłączający dobrą wiarę dłużnika spełniającego świadczenie do rąk cedenta ${ }^{73}$. Zbywca wierzytelności przestawał być uprawniony $z$ tytułu będącego przedmiotem transakcji prawa $z$ chwilą zawarcia umowy cesji i od tej chwili podmiotem wyłącznie uprawnionym do odbioru świadczenia oraz do dokonywania innych czynności dotyczących wierzytelności stawał się cesjonariusz. Świadczenie spełnione po przelewie do rąk cedenta oraz dokonana $z$ nim inna czynność skierowana na modyfikację lub umorzenie zobowiązania, mimo iż urzeczywistnione wobec podmiotu nielegitymowanego, były w drodze wyjątku od zasad ogólnych prawnie skuteczne aż do momentu zawiadomienia dłużnika o cesji przez cedenta lub cesjonariusza, względnie do momentu dokonania częściowej zapłaty na rzecz nabywcy wierzytelności.

W zaprezentowanej koncepcji dochodzi do przypisania rzymskiej notyfikacji oraz jej ekwiwalentowi takiego znaczenia prawnego, jakie ma ona w tych współczesnych systemach prawnych, które odmiennie niż prawo francuskie i włoskie, przyznają rozporządzeniu cesyjnemu charakter w pełni konsensualny ${ }^{74}$.

o quando gli è stata notificata. [2] Tuttavia, anche prima della notificazione, il debitore che paga al cedente non è liberato, se il cessionario prova che il debitore medesimo era a conoscenza dell'avvenuta cessione" - www.tutticodici.it.

${ }^{72}$ W. Rozwadowski, Przelew, cit., s. 199; R. Taubenschlag, op. cit., s. 217-219; R. SOHM - L. MitTEIS - L. WENGER, op. cit., s. 458-460.

${ }^{73}$ F. EISELE, op. cit., s. 49-50; K. LUIG, op. cit., s. 124.

${ }^{74} \S 1392$ ABGB: „Wenn eine Forderung von einer Person an die andere übertragen, und von dieser angenommen wird; so entsteht die Umänderung des Recht- 
W prawie austriackim omawianego zagadnienia dotyczą $\S 1395$ i $1396 \mathrm{ABGB}^{75}$. Według pierwszego z wymienionych przepisów, dopóki dłużnik nie wie o osobie cesjonariusza, może uiścić zapłatę do rąk dotychczasowego wierzyciela oraz dokonać $\mathrm{z}$ nim jakiejkolwiek innej czynności prawnej w związku $\mathrm{z}$ wierzytelnością. Już z tego unormowania wynika zatem a contrario, że dłużnik, który wie o cesji nie może skutecznie układać się ze swym dotychczasowym wierzycielem. Zasadę tę wyrażoną wprost znajdujemy w $\$ 1396$ in princ. $\mathrm{ABGB}$, według którego dłużnik po otrzymanej wiadomości o cesji nie może już świadczyć do rąk pierwszego wierzyciela, ani też dokonywać z nim skutecznie czynności prawnych dotyczących wierzytelności przelanej.

es mit Hinzukunft eines neuen Gläubigers. Eine solche Handlung heißt Abtretung (Zession), und kann mit, oder ohne Entgelt geschlossen werden"; § 398 BGB: , [1] Eine Forderung kann von dem Gläubiger durch Vertrag mit einem anderen auf diesen übertragen werden (Abtretung). [2] Mit dem Abschlusse des Vertrags tritt der neue Gläubiger an die Stelle des bisherigen Gläubigers"; co do prawa szwajcarskiego por. np. E. BUCHER, Schweizerisches Obligationenrecht, Allgemeiner Teil ohne Deliktsrecht, Zürich 1988, s. 536; co do prawa polskiego: art 170 $\S 1$ k.z.: „Nabywca wstępuje w prawa wierzyciela $\mathrm{z}$ chwilą zawarcia umowy o przelew wierzytelności”; art. $510 \S 1$ k.c.: „Umowa sprzedaży, zamiany, darowizny lub inna umowa zobowiązująca do przeniesienia wierzytelności przenosi wierzytelność na nabywcę, chyba że przepis szczególny stanowi inaczej albo że strony inaczej postanowiły", por. też A. OHANOwICZ, Zobowiazania. Zarys wedlug kodeksu cywilnego - część ogólna, Warszawa-Poznań 1965, s. 236.

${ }^{75} \S 1395$ ABGB: „Durch den Abtretungsvertrag entsteht nur zwischen dem Überträger (Zedent) und dem Übernehmer der Forderung (Zessionar); nicht aber zwischen dem letzten und dem übernommenen Schuldner (Zessus) eine neue Verbindlichkeit. Daher ist der Schuldner, solange ihm der Übernehmer nicht bekannt wird, berechtigt, den ersten Gläubiger zu bezahlen, oder sich sonst mit ihm abzufinden”; § 1396: „Dieses kann der Schuldner nicht mehr, sobald ihm der Übernehmer bekannt gemacht worden ist; allein es bleibt ihm das Recht, seine Einwendungen gegen die Forderung anzubringen. Hat er die Forderung gegen den redlichen Übernehmer für richtig erkannt; so ist er verbunden, denselben als seinen Gläubiger zu befriedigen" - www.ibiblio.org/ais/abgb4.htm\#t3h2; por. też Kommentar zum $A B G B$, red. P. Rummel, Wien 1984, s. 2634-2639; S. WRóBlewski, Powszechny austriacki kodeks cywilny, część druga, Kraków 1918. 
Stosownie do $\S 407 \mathrm{BGB}^{76}$ nowy wierzyciel (cesjonariusz) musi uznać za skuteczne względem siebie świadczenie, którego dłużnik dokona po przelewie na rzecz dotychczasowego wierzyciela, a także każdą inną czynność prawną, która po przelewie zostanie przedsięwzięta między dłużnikiem a dotychczasowym wierzycielem odnośnie do wierzytelności, chyba że dłużnik wie o przelewie w chwili świadczenia lub dokonywania czynności prawnej.

Zakres przesłanki wyłączającej możliwość zniesienia lub modyfikacji więzi obligacyjnej $w$ drodze czynności między dłużnikiem a zbywcą wierzytelności jest więc w świetle przytoczonych unormowań szerszy niż w prawie rzymskim. W świetle bowiem literalnej interpretacji C. 8,41,3 pr., wyjęcie stosunku obligacyjnego, z którego wynikała będąca przedmiotem przelewu wierzytelność, ze sfery oddziaływań cedenta następowało $\mathrm{z}$ chwilą, gdy debitor cessus otrzymywał zawiadomienie o przelewie, pochodzące od cesjonariusza, a nadto $\mathrm{w}$ razie spełnienia przez dłużnika częściowego świadczenia na rzecz nabywcy. Sama wiedza dłużnika o przelewie, w sytuacji braku denuntiationis, nie miała zasadniczo znaczenia prawnego i nie uchylała ochrony dłużnika, chyba że została uzewnętrzniona i zobiektywizowana przez aliquid praestare do rąk cesjonariusza. Według $\S \S 1395$ i 1396 ABGB oraz $\S 407$ BGB wystarcza natomiast, że dłużnik w chwili zapłaty cedentowi lub dokonania $\mathrm{z}$ nim innej czynności prawnej obejmuje zaistniały przelew swą świadomością. Powołane przepisy nie przyznają zatem notyfikacji charakteru samoistnego i kwalifikowanego, lecz zrównują ją z innymi ewentualnymi źródłami, z których cessus uzyskać może informację o zaistnieniu przelewu,

${ }^{76} \S 407$ BGB (1): „Der neue Gläubiger muß eine Leistung, die der Schuldner nach der Abtretung an den bisherigen Gläubiger bewirkt, sowie jedes Rechtsgeschäft, das nach der Abtretung zwischen dem Schuldner und dem bisherigen Gläubiger in Ansehung der Forderung vorgenommen wird, gegen sich gelten lassen, es sei denn, daß der Schuldner die Abtretung bei der Leistung oder der Vornahme des Rechtsgeschäfts kennt"; por. też Münchener Kommentar zum Bürgerlichen Gesetzbuch, red. H. HeINRICHS, II, München 1994, s. 1638; H. BroX, Allgemeines Schuldrecht, München 1998, s. 240-241; H. FIKENTSCHER, Schuldrecht, Berlin-New York 1997, s. 363-364. 
przesłanką uchylającą ochronę dłużnika czynią natomiast samą pozytywną wiedzę dłużnika o cesji ${ }^{77}$. Konsekwencją tak daleko posuniętej subiektywizacji są utrudnienia dowodowe. W każdym bowiem przypadku, gdy cessus pozyskuje informacje o przelewie, nawet wówczas, gdy informacja ta pochodzi od jednej ze stron umowy cesyjnej, zachodzi konieczność badania, czy jest wiarygodna i czy ma, w świetle ogólnie przyjętych, obiektywnych reguł wykładni, zdolność wygenerowania wiedzy debitoris o fakcie cesji ${ }^{78}$. Przedmiotem dowodu jest bowiem w tym przypadku sama wiedza dłużnika o zmianie osoby uprawnionej, a więc okoliczność czysto subiektywna, nie zaś obiektywny i łatwiejszy do wykazania fakt notyfikacji lub częściowej zapłaty na ręce nowego wierzyciela. Zaznaczyć należy jednak, iż wbrew stylizacji C. 8,41,3 pr., były już na gruncie literatury romanistycznej reprezentowane poglądy, w myśl których przesądzające znaczenie ma w każdym przypadku sama wiedza dłużnika o przelewie - ilekroć debitor o cesji wiedział, nie mogło być mowy o przyznaniu jego świadczeniu do rąk cedenta skutku zwalniającego, niezależnie od tego, czy miała miejsce denuntiatio oraz bez względu na to, czy dłużnik spełnił częściowe świadczenie na rzecz cesjonariusza ${ }^{79}$.

Prawo szwajcarskie w art. 167 c.o..$^{80}$ przesądza, iż dłużnik jest wolny od zobowiązania, jeżeli zanim został zawiadomiony o przelewie

\footnotetext{
${ }^{77}$ R. STÜRNER, [w:] Bürgerliches Gesetzbuch mit Gesetz zur Regelung des Rechts der Allgemeinen Geschäftbedingungen, red. O. JAUERNIG, München 1997, s. 392-394; O. von GIERKE, Deutsches Privatrecht - Schuldrecht, München-Leipzig 1917, s. 194-195; H. FIKENTSCHER, op. cit., s. 363-364; K. LARENZ, Lehrbuch des Schuldrechts, I: Allgemeiner Teil, München 1987, s. 588-590; H. BROX, op. cit., s. 240-241.

${ }^{78}$ R. LONGCHAMPS DE BÉRIER, Uzasadnienie projektu kodeksu zobowiązań z uwzględnieniem ostatecznego tekstu kodeksu, Warszawa 1936, s. 260; K. ZAWADA, Ochrona diużnika, cit., s. 10.

${ }^{79}$ K. LUIG, op. cit., s. 120: „... schon die bloße Kenntnis des Schuldners von der geschehenen Abtretung die Möglichkeit einer befreienden Zahlung an den Altgläubiger ausschließe, da nur der gute Glaube des Schuldners aus Billigkeit Schutz verdiene ...".

${ }^{80}$ Art. 167 c.o.: „Le débiteur est valablement liberé si, avant que la cession ait été porte à sa connaissance par le cédant ou le cessionnaire, il paie de bonne foi entre
} 
przez cedenta lub cesjonariusza, spełnił w dobrej wierze świadczenie do rąk dotychczasowego wierzyciela lub, w przypadku przelewu wielokrotnego, do rąk cesjonariusza, względem którego innemu cesjonariuszowi przysługiwało prawo pierwszeństwa. Porównując przyjęte tu rozwiązanie z pierwowzorem rzymskim można zauważyć, iż cechą wspólną jest element bezpośrednio do dłużnika skierowanej, normatywnie wyodrębnionej notyfikacji, mającej status samoistny i kwalifikowany, dla której dokonania w obu wypadkach nie wymagano formy pisemnej. Różnica zaś polega przede wszystkim na znaczącym rozszerzeniu zakresu drugiej przesłanki. Do odmówienia działaniom debitoris w stosunkach ze zbywcą skuteczności prawnej nie jest konieczne, by cessus dawał obiektywny dowód swej wiedzy o cesji w postaci zapłaty należności nowemu wierzycielowi - wystarcza, że $\mathrm{w}$ chwili świadczenia nie jest $\mathrm{w}$ dobrej wierze, i.e. wie o cesji lub w świetle obiektywnych okoliczności może i powinien wiedzieć ${ }^{81}$.

Stosownie do art. 173 polskiego kodeksu zobowiązań ${ }^{82}$ notyfikacja miała charakter samoistny, przybierała formę pisemną oraz mogła pochodzić zarówno od zbywcy jak i od nabywcy wierzytelności. Równoważna w skutkach z zawiadomieniem była wiedza dłużnika o zaistniałym przelewie w chwili zapłaty długu lub dokonania innej czynności $z$ poprzednim wierzycielem ${ }^{83}$. Wymóg pisma nie miał

les mains du précédant créancier ou dans le cas de cessions multiples, entre les mains d'un cessionnaire auquel un autre a le droit d'être préféré" - www.admin.ch.

${ }^{81}$ K. ZAWADA, Ochrona dtużnika, cit., s. 10-11; A. SCHNEIDER - H. FICK F. FICK, Commentaire du Code fédéral des obligations, Neuchâtel 1915, s. 303; V. RosSEL, Manuel du droit fédéral des obligations, I, Lausanne-Généve 1920, s. 230-231.

${ }^{82}$ Art. 173 k.z.: „Dopóki dłużnik nie otrzymał zawiadomienia na piśmie o przelewie wierzytelności od zbywcy albo od nabywcy, zapłata dokonana poprzedniemu wierzycielowi oraz czynności prawne $\mathrm{z}$ nim zdziałane mają skutek przeciwko nabywcy, chyba że dłużnik wiedział o dokonanym przelewie w chwili zapłaty długu lub w chwili zawarcia czynności z poprzednim wierzycielem"; por. też J. KorzONEK - I. RosenblüTH, Kodeks Zobowiazań. Komentarz, I, Kraków 1936; M. KuRman, Kodeks zobowiązań. Podręcznik praktyczny, Warszawa 1938.

${ }^{83}$ J. HorowsKi, op. cit., s. 11; A. FISCHLER, O przelewie wierzytelności wedtug kodeksu zobowiqzań, «Głos Prawa» 2 (1934), s. 160; R. LONGCHAMPS DE BÉRIER, 
znaczenia dowodowego, lecz stanowił element konstytutywny zdarzenia prawnego, $\mathrm{z}$ którym ustawa wiązała skutek $\mathrm{w}$ postaci uchylenia dalszej ochrony dobrej wiary dłużnika ${ }^{84}$. Pisemne zawiadomienie o przelewie wyłączało wobec nowego wierzyciela skuteczność świadczenia bądź innej czynności prawnej zdziałanej w stosunkach między dłużnikiem a cedentem, bez względu na swoją wiarygodność, niezależnie od tego, czy budziło wątpliwości co do swej zgodności z rzeczywistym stanem rzeczy i czy było na tyle prawdopodobne, że w świetle ogólnie przyjętych obiektywnych reguł wykładni było w stanie przekonać dłużnika o tym, że przelew miał miejsce wygenerować jego wiedzę o fakcie cesji. Jeśli dł́użnik nie został przez żadną ze stron zawiadomiony o tym, że przelew miał miejsce, nie mógł wywodzić, iż skutecznie zwolnił się ze zobowiązania świadcząc do rąk zbywcy lub dokonując z nim innej czynności, ilekroć w chwili świadczenia lub czynności wiedział o tym, że wierzytelność została przelana. Chodziło przy tym o rzeczywistą wiedzę, nie wystarczało, że mógł i powinien był wiedzieć. Ciężar udowodnienia, że dłużnik o przelewie wiedział, spoczywał na tym, kto wywodził $\mathrm{z}$ tego faktu skutki prawne $-\mathrm{z}$ reguły zatem na cesjonariuszu dochodzącym a debitore ponownego świadczenia.

Według art. 512 obecnie obowiązującego polskiego kodeksu cywilnego ${ }^{85}$, dopóki zbywca nie zawiadomił dłużnika o przelewie, spełnienie świadczenia do rąk poprzedniego wierzyciela ma skutek względem nabywcy, chyba że w chwili spełniania świadczenia dłuż-

Uzasadnienie, cit., s. 259-260; TEnŻE, Zobowiqzania, Poznań 1948, s. 307-308; J. KorzoneK - I. Rosenblüth, Kodeks Zobowiqzań. Komentarz, cit., s. 382-385.

${ }^{84}$ R. LONGCHAMPS DE BÉRIER, Uzasadnienie, cit., s. 260-261.

${ }^{85}$ Art. 512 k.c.: „Dopóki zbywca nie zawiadomił dłużnika o przelewie, spełnienie świadczenia do rąk poprzedniego wierzyciela ma skutek względem nabywcy chyba że w chwili spełnienia świadczenia dłużnik wiedział o przelewie. Przepis ten stosuje się odpowiednio do innych czynności prawnych dokonanych między dłużnikiem a poprzednim wierzycielem"; por. też G. BIENIEK - H. CIEPEA - S. DMOWSKI - J. GUDOWSKI - K. KOŁAKOWSKI - M. SYCHOWICZ - T. WIŚNIEWSKI - C. ŻUŁAWSKA, Komentarz do kodeksu cywilnego, Księga trzecia - Zobowiqzania, I, Warszawa 2001. 
nik wiedział o przelewie. Z mocy wyraźnej dyspozycji ustawodawcy, przepis ten stosuje się odpowiednio do innych czynności prawnych dokonanych między dłużnikiem a poprzednim wierzycielem. Okolicznościami wyłączającymi ochronę są zatem posiadające samodzielny status, pochodzące od zbywcy zawiadomienie dłużnika o przelewie oraz rzeczywista wiedza dłużnika o przelewie, istniejąca w chwili spełnienia świadczenia lub dokonania innej czynności prawnej $\mathrm{z}$ cedentem. Notyfikacja może być dokonana również w formie ustnej. Istotne, iż bezwzględny skutek uchylenia ochrony dłużnika wywoła jedynie zawiadomienie o cesji pochodzące od cedenta, tylko ono ma bowiem w świetle art. 512 k.c. charakter przesłanki samodzielnej. W konsekwencji, ilekroć pochodząca od zbywcy denuntiatio przybierze formę pisemną, już samo wykazanie, że notyfikacja dotarła do dłużnika w sposób umożliwiający mu zapoznanie się z nią, wystarcza do zniesienia debitoris bonae fidei, nawet jeżeli cessus w istocie nie zapoznał się z treścią zawiadomienia. Denuntiatio pochodząca od nabywcy wierzytelności zrównana jest natomiast z innymi potencjalnymi źródłami, z których cessus mógł czerpać wiedzę o cesji, gdyż w tym przypadku to wiedza debitoris, a nie zawiadomienie stanowią element stanu faktycznego uchylający dobrą wiarę. Jeżeli więc o przelewie powiadamia cesjonariusz, nie wystarczy wykazanie, że debitor cessus otrzymał zawiadomienie w sposób umożliwiający zapoznanie się z nim, niezbędne staje się wykazanie, że dłużnik miał w chwili spełniania świadczenia do rąk cedenta lub dokonywania $\mathrm{z}$ nim innej czynności dotyczącej wierzytelności rzeczywistą wiedzę o zmianie osoby wierzyciela.

V. ZAGADNIENIE NOTYFIKACJI W PRAWIE ANGIELSKIM ORAZ W ŚWIETLE POSTANOWIEŃ RESTATEMENT SECOND OF CONTRACTS I UNIFORM COMMERCIAL CODE

W prawie angielskim forma i znaczenie notyfikacji cesyjnej (notice to debtor) kształtuje się różnie w zależności od charakteru przelewu - inaczej w odniesieniu do statutory assignment, inaczej przy cesji opartej na zasadach equity (equitable assignment). W pierw- 
szym przypadku zawiadomienie dłużnika powinno mieć formę pisemną, a pochodzić może zarówno od cedenta, jak i od cesjonariusza. Jakkolwiek nie ma wymogu użycia konkretnych, ściśle określonych sformułowań, niezbędne jest, by notice zawierała wyraźne i bezwarunkowe polecenie zapłaty osobie trzeciej, określonej w sposób nie budzący wątpliwości jako cesjonariusz, a nie np. jako pełnomocnik ustanowiony celem inkasa ${ }^{86}$. Nieskuteczne jest zawiadomienie zawierające niezgodne $\mathrm{z}$ rzeczywistością określenie daty przelewu oraz kwoty należności, jednakże notyfikacja nie zawierająca żadnych danych w tych kwestiach może być uznana za skuteczną, jeżeli tylko opisuje dług $\mathrm{z}$ dokładnością pozwalającą na jego bezsporną identyfikację. Zawiadomienie przesłane pocztą wywołuje skutek w chwili, gdy dłużnik je otrzymał ${ }^{87}$.

Brak notyfikacji powoduje nieskuteczność statutory assignment. Dopuszcza się w takim przypadku sui generis konwersję - możliwość uznania nie wywołującego skutków prawnych statutory assignment za przelew prawnie skuteczny w świetle equity. Denuntiatio nie jest bowiem w przypadku equitable assignment niezbędną przesłanką perfekcji praw cesjonariusza względem debitoris cessus, a jej znaczenie polega tu na tym, iż, zanim zostanie uczyniona, dłużnik jest uprawniony do uważania cedenta za swego wierzyciela i do spełnienia na jego rzecz świadczenia ze skutkiem zwalniającym ${ }^{88}$.

Według prawa kontraktowego obowiązującego w Stanach Zjednoczonych cesja, podobnie jak w prawie austriackim, niemieckim, szwajcarskim czy polskim ma charakter czynności konsensualnej i rozporządzającej. Z chwilą zawarcia umowy przelewu cesjonariusz wstępuje $\mathrm{w}$ prawa cedenta, a dla ważności aktu nie wymaga się zgody dłużnika. Niemniej jednak, aby cesja była w pełni efektywna, wymagane jest, by dłużnik został powiadomiony o przelewie i o osobie nowego wierzyciela. W przeciwnym razie cessus zachowuje możliwość świadczenia do rąk cedenta ze skutkiem zwalniają-

\footnotetext{
${ }^{86}$ G.H. TREITEL, The law of contracts, London 1987, s. 505.

${ }^{87}$ F.R. DAvies, Contract, London 1986, s. 204; G.H. Treitel, op. cit. , s. 505-506.

${ }^{88}$ F.R. DAVIES, op. cit., s. 204; G.H. TREITEL, op. cit., s. 505-506.
} 
cym, bądź modyfikowania treści więzi obligacyjnej przez czynności prawne $\mathrm{z}$ nim zdziałane ${ }^{89}$. Dla zawiadomienia nie wymaga się żadnej szczególnej formy, pod warunkiem wszakże, że z odpowiednim stopniem precyzji identyfikuje ono prawo, które zostało zbyte, określa wysokość dłużnej sumy, objętej przelewem, oraz wskazuje osobę cesjonariusza ${ }^{90}$. Notyfikacja może pochodzić zarówno od cedenta jak i od cesjonariusza, jeżeli jednak pochodzi od nabywcy wierzytelności, dłużnik może domagać się przedłożenia stosownego dowodu cesji (adequate proof of the assignment) ${ }^{11}$. Zawiadomienie powinno być otrzymane przez dłużnika, to jest dojść do jego świadomości lub przynajmniej zostać doręczone w sposób stwarzający możliwość zapoznania się z nim².

Jeżeli cessus wykonuje zobowiązanie na rzecz cedenta przed otrzymaniem notyfikacji, stosunek obligacyjny ulega umorzeniu, a dłużnik nie ponosi żadnej odpowiedzialności względem cesjonariusza $^{93}$. Jeżeli natomiast dłużnik, lekceważąc otrzymane zawiadomienie, świadczy cedentowi, ponosi względem nabywcy wierzytelności odpowiedzialność, która wyrazi się bądź w obowiązku speł-

${ }^{89}$ Restatement, Second, Contracts - $\$ 338(1)$ : „Except as stated in this Section, notwithstanding an assignment, the assignor retains his power to discharge or modify the duty of the obligor to the extent that the obligor performs or otherwise gives value until but not after the obligor receives notification that the right has been assigned and that performance is to be rendered to the assignee".

${ }^{90}$ UCC. $\S 9-318(3)$; por. też B.A. BLUM, Contracts. Examples and explanations, cit., s. 677; E.A. FARNSworTH - A. MCCORMACK, Contracts, cit., s. 777-778.

${ }^{91}$ UCC. $\$ 9-318(3)$ : ,if there is doubt as to the adequacy either of a notification or of proof submitted after request, the account debtor may not be safe in disregarding this unless he has notified the assignee with commercial promptness as to the respects in which identification or proof is considered defective"; por. też B.A. Blum, op. cit., s. 677; E.A. FARNSwORTH - A. MCCORMACK, op. cit., s. 778.

${ }^{92}$ UCC. § 1-201(26) stanowi, że osoba otrzymuje notyfikację, jeżeli ta bądź dociera bezpośrednio do jej świadomości, bądź też jest jej doręczona w sposób umożliwiający zapoznanie się z nią, sc. w miejscu przeznaczonym do odbioru tego rodzaju informacji.

${ }^{93}$ B.A. Blum, op. cit., s. 677; E.A. Farnsworth - A. McCormack, op. cit., s. $777-778$. 
nienia do jego rąk świadczenia, bądź w formie zapłaty odszkodowania ${ }^{94}$.

Wyłączenie wpływu cedenta na zbytą wierzytelność z chwilą notyfikacji nie ma charakteru bezwzględnego w przypadku cesji uprawnień z kontraktu wzajemnego. Gdy obie strony są względem siebie zobowiązane i uprawnione, a przedmiotem przelewu staje się prawo jednej ze stron do otrzymania określonego świadczenia od kontrahenta, powstaje sytuacja szczególna o tyle, że przenoszone na cesjonariusza prawo jest tu zależne od wykonania przez cedenta na rzecz dłużnika określonego świadczenia wzajemnego. W takim przypadku również post denuntiationem dopuszczona jest możliwość dokonania w stosunkach między zbywçą prawa a dłużnikiem modyfikacji kontraktu ze skutkiem dla cesjonariusza (the assignee acquires corresponding rights under the modified or substituted contract), pod warunkiem, że zmiany wprowadzane są w dobrej wierze (in good faith) i nie naruszają zasad prawidłowej gospodarki (in accordance with reasonable commercial standards) ${ }^{95}$.

\section{WNIOSKI KOŃCOWE}

Refleks rzymskiego modelu denuntiationis w licznych ustawodawstwach współczesnych jest widoczny, a kierunki modyfikacji wzorca dają się ująć w trzech zasadniczych kategoriach. Występujące w omawianym zakresie odmienności dotyczą po pierwsze kwestii znaczenia

${ }^{94}$ UCC. $\$ 9-318(3)$ : „account debtor is authorized to pay the assignor until the account debtor receives notification"; Restatement, Second, Contracts - $\$ 338$ „assignor retains the power to discharge the duty of the obligor ... until but not after the obligor receives notification"; por. też B.A. BLUM, op. cit., s. 676-677; E.A. FARNSWORTH - A. MCCORMACK, op. cit., s. 778,

${ }^{95}$ Restatement, Second, Contracts $\S 338(2)$ : „So far as an assigned right is conditional on the performance of a return promise, and notwithstanding notification of the assignment, any modification of or substitution for the contract made by the assignor and obligor in good faith and in accordance with reasonable commercial standards is effective against the assignee. The assignee acquires corresponding rights under the modified or substituted contract". 
prawnego denuncjacji, po drugie zagadnień jej natury technicznej, a w szczególności określenia podmiotu uprawnionego do notyfikacji oraz formy, jaką przybierała, po trzecie wreszcie problemu jej ekwiwalentów, i.e. pewnych stanów faktycznych, które z woli ustawodawcy wywołują identyczne jak notyfikacja skutki prawne.

1) Przypisywane notyfikacji z C. $8,41,3$ pr. znaczenie prawne uzależnione jest od tego, która spośród zaprezentowanych w literaturze hipotez w przedmiocie jurydycznego charakteru rzymskiej cesji posłuży za podstawę rozważań. Zanegowanie tezy o wykształceniu pod wpływem reform prawa cesarskiego przelewu jako formy pochodnego nabycia wierzytelności pod tytułem szczególnym implikuje przypisanie notyfikacji, o której mówi reskrypt Gordiana, funkcji elementu systemu ochrony pozycji prawnej cesjonariusza ante litem contestatam. W tym ujęciu denuntiatio staje się oddanym do dyspozycji nabywcy wierzytelności instrumentem, pozwalającym mu już w fazie in iure wyłączyć wpływ cedenta na będące przedmiotem transakcji prawo. Stanowisko dopatrujące się w rzymskiej cesji, od czasu wyposażenia nabywcy w actionem utilem, znamion sukcesji syngularnej, nie ma $\mathrm{z}$ kolei charakteru jednorodnego, a niejednorodność ta związana jest $\mathrm{z}$ istnieniem dwóch możliwych rozwiązań w kwestii skutków prawnych denuntiationis. Zakładając czysto obligacyjną naturę umowy stanowiącej podstawę przelewu, wypada przypisać notyfikacji charakter przesłanki skuteczności rozporządzenia cesyjnego, potraktować ją jako stan faktyczny, z którego zaistnieniem wierzytelność ostatecznie przestawała stanowić aktyw cedenta i wchodziła do majątku cesjonariusza ${ }^{96}$. Pogląd o podwójnym, zobowiązująco-rozporządzającym skutku umowy cesji ${ }^{7}$ prowadzi natomiast do ujmowania denuncjacji w kategoriach zdarzenia prawnego wyznaczającego końcowy moment okresu, w którym dłużnik korzysta z ochrony dobrej wiary.

\footnotetext{
${ }^{96}$ J. RzodKowsKI, op. cit., s. 47; G. MAY, op. cit., s. 404; K. LUIG, op. cit., s. 118-119.

${ }^{97}$ W. Rozwadowski, Przelew, cit., s. 199; R. Taubenschlag, op. cit., s. 217-219; R. SOHM - L. MITTEIS - L. WENGER, op. cit., s. 458-460.
} 
Spośród współczesnych systemów prawnych jako cessionis condicio iuris traktują denuncjację prawo francuskie oraz prawo włoskie, przy czym w obu przypadkach chodzi jedynie o skuteczność zewnętrzną sc. wobec dłużnika. Prawo austriackie, niemieckie i szwajcarskie, prawo polskie - zarówno na gruncie kodeksu cywilnego, jak i w świetle poprzedzającego go w zakresie prawa obligacyjnego kodeksu zobowiązań, a nadto unormowania amerykańskie, zawarte m.in. w Uniform Commercial Code oraz Restatement Second of Contracts, wiążą z denuncjacją jedynie skutek wyłączenia dobrej wiary dłużnika.

Notyfikacja może mieć charakter kwalifikowanego, samoistnego i obiektywnego czynnika odbierającego dłużnikowi prawo powoływania się na swą ignorantionem, bądź być jedynie źródłem informacji, z którego cessus czerpie wiedzę o przelewie, przy czym ta wiedza właśnie, a nie sama notyfikacja, stanowią przesłankę uchylającą bonam fidem debitoris. Różnica jest bardzo istotna, bowiem ilekroć denuntiatio ma status samodzielny, odpadają utrudnienia dowodowe związane z koniecznością wykazywania subiektywnej okoliczności, jaką stanowi wiedza dłużnika o przelewie, oceniania, w jakim stopniu informacje, które dłużnik otrzymał o cesji były wiarygodne i czy wywołałyby u przeciętnego, obiektywnego uczestnika obrotu przekonanie, że cesja miała miejsce. Konstrukcja notyfikacji kwalifikowanej usuwa ten problem, gdyż z reguły wystarczające jest tu wykazanie, że zawiadomienie w ogóle miało miejsce i doszło do dłużnika w taki sposób, że mógł się z nim bez przeszkód zapoznać.

Pierwowzoru koncepcji zawiadomienia o charakterze przesłanki samoistnej dostarcza już Codex Iustinianus, gdzie wyraźnie dochodzi do głosu obiektywizująca zasada formalizmu, podnosząc do rangi stanów faktycznych uchylających ochronę dobrej wiary dłużnika jedynie denuncjację oraz wiedzę dłużnika o cesji, uzewnętrznioną $\mathrm{w}$ formie aliquid praestare na rzecz cesjonariusza ${ }^{98}$. Zagadnienie skutków samej nieformalnej wiedzy debitoris o zmianie wierzyciela nie jest w literaturze romanistycznej rozstrzygane jednoznacznie.

${ }^{98}$ H. Derniurg, op. cit., s. 129-130. 
Literalna wykładnia C. 8,41,3 prowadzi do wniosku, iż dwa wskazane w omawianym fragmencie źródłowym elementy - notyfikacja i akceptacja przez częściowe świadczenie wyczerpują zakres przypadków, w których dłużnik nie może powoływać się na brak wiedzy o cesji jako okoliczność uzasadniającą spełnienie świadczenia do rąk cedenta. W braku zaistnienia wspomnianych zobiektywizowanych przesłanek, sama wiedza debitoris o zmianie wierzyciela jest, zgodnie $\mathrm{z}$ brzmieniem wyrażonej tu normy, pozbawiona relewancji prawnej. Można jednak spotkać pogląd, w myśl którego w każdym przypadku, gdy cessus wiedział o przelewie płacąc dług do rąk cedenta, nie może liczyć na skutek zwalniający swego świadczenia ${ }^{99}$. Zgodnie z taką rozszerzającą interpretacją C. 8,41,3 pr., przesłanki wyłączające dobrą wiarę dłużnika byłyby więc w sumie trzy - dwie wymienione expressis verbis $\mathrm{w}$ będącym przedmiotem analizy fragmencie źródłowym, a nadto bloße Kenntnis des Schuldners.

Niezależnie od tego, czy stany faktyczne z C. 8,41,3 pr. uznamy za wyłączne, czy też podzielimy pogląd przypisujący znaczenie prawne również nieformalnej wiedzy debitoris o przelewie, podkreślić należy samoistność rzymskiej notyfikacji, wyrażającą się w tym, że gdyby pozwany przez cesjonariusza dłużnik zasłonił się zarzutem uprzedniej zapłaty do rąk cedenta, wystarczy, by nabywca wierzytelności wykazał, iż dokonał notyfikacji lub ewentualnie, że otrzymał z rąk dłużnika częściowe świadczenie. Normatywnie, a w pewnym wąskim zakresie przypadków również praktycznie, odrywa się denuntiatio od rzeczywistej wiedzy dłużnika. Samo udowodnienie zaistnienia obiektywnych przesłanek w postaci notyfikacji lub akceptacji per aliquid praestare przesądza bowiem, iż świadczenie debitoris do rąk cedenta nie może być ujmowane w kategoriach skutecznego zwolnienia się ze zobowiązania. W braku tych okoliczności, zgodnie z koncepcją opartą na gramatycznej wykładni C. 8,41,3 pr.,

${ }^{99}$ K. LuIG, op. cit., s. 120: „... schon die bloße Kenntnis des Schuldners von der geschehenen Abtretung die Möglichkeit einer befreienden Zahlung an den Altgläubiger ausschließe, da nur der gute Glaube des Schuldners aus Billigkeit Schutz verdiene ...". 
dłużnik był zwolniony ze zobowiązania nawet jeśli świadcząc cedentowi wiedział, że accipiens nie jest materialnie uprawniony. Stosownie do alternatywnego poglądu, w opisanej sytuacji, nabywca mógł jeszcze bezpośrednio wykazywać rzeczywistą wiedzę debitoris o przelewie, a jeśli dowód się powiódł, uzyskiwał zasądzenie dłużnika na ponowne świadczenie.

System notyfikacji samoistnej przyjmuje prawo francuskie, gdzie zresztą również, podobnie jak na gruncie dosłownie interpretowanego C. 8,41,3 pr., sama „nieformalna” wiedza dłużnika w przedmiocie przelewu nie ma znaczenia, co stwarza możliwość działania w złej wierze i otwiera drogę do nadużyć. Dopiero orzecznictwo wychodzi poza warstwę gramatyczną ustawy, uwzględnia w pewnym zakresie przypadków okoliczność, czy dłużnik obejmował swą świadomością fakt zmiany osoby wierzyciela, $\mathrm{i} w$ ten sposób chroni interes cesjonariusza.

W prawie włoskim mamy do czynienia z podobną sytuacją, aczkolwiek obok formalnej i samoistnej notyfikacji oraz akceptacji, warunkujących skuteczność przelewu erga debitorem, występuje racjonalizująca system przesłanka wiedzy, która wyklucza skutek zwalniający zapłaty dokonanej przez świadomego podmiotowej zmiany zobowiązania dłużnika do rąk cedenta, przed dopełnieniem formalności $z$ art. 1265 cod. civ.

Prawo austriackie i niemieckie nie przewidują przesłanki notyfikacji samoistnej, posługując się jedynie subiektywnym znamieniem wiedzy dłużnika o przelewie. Dla porząaku nadmienić należy w tym miejscu, że odnośnie do prawa niemieckiego stwierdzenie powyższe dotyczy jedynie sytuacji świadczenia lub innej czynności zaistniałych post cessionem $\mathrm{w}$ stosunkach między dłużnikiem a cedentem, tj. zagadnienia unormowanego w $\S 407$ BGB. Już bowiem $\S 409$ BGB, normujący komplementarną problematykę zwalniającego skutku świadczenia do rąk cesjonariusza w przypadku cessionis non existentis lub non efficientis, posługuje się elementem notyfikacji kwalifikowanej (Anzeige).

Denuntiatio ma charakter samoistny i kwalifikowany w prawie szwajcarskim, polskim, angielskim, a także w świetle rozwiązań Uniform Commercial Code i Restatement Second of Contracts. 
2) Zgodnie $z$ literalnym brzmieniem C. $8,41,3$ pr., zawiadomienie o przelewie pochodzi od cesjonariusza. W drodze argumentu a maiori ad minus przyjmowano niekiedy, że w praktyce notyfikacji mogły dokonać obie strony umowy przelewu ${ }^{100}$. Jeżeli przyjmiemy, $\dot{z}$ e do istoty denuntiationis należy jej wiarygodność, nie ulega wątpliwości, iż zgodnie $z$ typowym rozkładem interesów w stosunkach cedent - cesjonariusz, przy założeniu braku motywów pozaekonomicznych, praktycznie wykluczone jest, by notyfikacja pochodząca od zbywcy była niezgodna $\mathrm{z}$ rzeczywistym stanem rzeczy, zachodzi natomiast ryzyko fałszywego zawiadomienia o cesji, pochodzącego od cesjonariusza. A więc, jeżeli dopuszczalna jest denuntiatio ze strony nabywcy, tym bardziej dozwolone jest, by de cessione zawiadamiał cedent. Podobnie przyjmuje się $\mathrm{w}$ systemie francuskim ${ }^{101}$ i włoskim. W prawie austriackim i niemieckim kwestia jest poniekąd bezprzedmiotowa - fakt, iż zawiadomić o przelewie może zarówno cedent jak i cesjonariusz nie budzi wątpliwości, gdyż §§ 1395 i 1396 ABGB oraz $\$ 407$ BGB nie posługują się znamieniem notyfi-

${ }^{100}$ F. EISELE, op. cit., s. 50; R. SOHM - L. MitTEIS - L. WENGER, op. cit., s. 457-459. Pogląd ten koresponduje przede wszystkim ze stanowiskiem zakładającym, że denuntiatio ze strony nabywcy i częściowe świadczenie na rzecz cesjonariusza wyczerpują zakres okoliczności wyłączających dobrą wiarę dłużnika, sama zaś nieformalna wiedza o zmianie wierzyciela nie ma w tej kwestii znaczenia prawnego. Przy takim założeniu szczególnie uzasadnione wydaje się przyjęcie, iż równoznaczne $\mathrm{z}$ denuncjacją pochodzącą od cesjonariusza jest zawiadomienie dłużnika o cesji pochodzące od zbywcy. W przeciwnym przypadku uprawniony byłby wniosek, że cessus, którego cedent poinformował o przelewie, może mimo to zapłacić dług do jego rąk i zwolnić się w ten sposób ze zobowiązania. Jeżeli przyjąć natomiast, że wbrew dosłownemu brzmieniu C. 8,41,3 pr. sama wiedza debitoris o cesji uchylała jego dobrą wiarę, traktowanie notyfikacji pochodzącej od cedenta na równi z denuntiatio cesjonariusza miałoby również pewne znaczenie, lecz mniejsze - prowadziłoby mianowicie do wyodrębnienia jej spośród całokształtu potencjalnych źródeł informacji o przelewie i do nadania jej charakteru denuncjacji kwalifikowanej - samodzielnej, normatywnie odróżnionej od stanu świadomości dłużnika przesłanki wyłączającej bonam fidem.

${ }^{101}$ F. Terré - P. Simler - Y. Lequette, Droit civil. Les obligations, Paris 1996, s. 950 . 
kacji kwalifikowanej, lecz wyłącznie subiektywną przesłanką wiedzy dłużnika, której źródło nie jest przecież w żaden sposób zdeterminowane. W świetle regulacji prawa szwajcarskiego, angielskiego oraz amerykańskiego, notyfikacja może pochodzić zarówno od zbywcy, jak i od nabywcy wierzytelności. Identyczne rozwiązanie przewidywał polski kodeks zobowiązań. Odmiennie stanowi obecnie obowiązujący polski kodeks cywilny, przewidując, że zawiadomienie debitoris cessus o przelewie tylko wówczas ma charakter kwalifikowany, gdy pochodzi od cedenta.

Codex Iustinianus nie przewidywał ograniczeń co do formy notyfikacji - mogła być dokonana zarówno w formie ustnej jak i w formie pisemnej. Spośród ustawodawstw nowożytnych zasadę bezformalności przyjmują w omawianym zakresie prawo austriackie, niemieckie, szwajcarskie, polski kodeks cywilny, a także prawo amerykańskie. W systemie angielskim przy equitable assignment notyfikacja może mieć formę ustną, w przypadku statutory assignment natomiast, dłużnik powinien otrzymać zawiadomienie na piśmie ${ }^{102}$. Polski kodeks zobowiązań wymagał, by zawiadomienie miało charakter pisemny.

3) Jak była już o tym mowa, w świetle dosłownej interpretacji C. 8,41,3 pr., w prawie rzymskim sama wiedza dłużnika o przelewie w chwili zapłaty cedentowi bądź w chwili dokonania $z$ nim innej czynności prawnej dotyczącej wierzytelności przelanej nie miała prawnego znaczenia. Ekwiwalentem notyfikacji było natomiast częściowe spełnienie przez dłużnika świadczenia na rzecz cesjonariusza. Płacąc dług do rąk nabywcy wierzytelności, cessus konkludentnie ujawniał tym samym, że o cesji wie. Wiedza dłużnika o przelewie, aby mogła wywołać skutki równoznaczne z denuncjacją, musiała zatem uzewnętrznić się $\mathrm{w}$ precyzyjnie określonym, obiektywnie stwierdzalnym jego zachowaniu. Według innego poglądu, wiedza debitoris o cesji nie może być uznana za prawnie irrelewantną. Nawet w braku notyfikacji i akceptacji możliwe jest pod-

${ }^{102}$ G.H. TREITEL, op. cit., s. 505. 
ważenie bonam fidem dłużnika przez wykazanie, że faktycznie obejmował on swą świadomością zmianę wierzyciela ${ }^{103}$.

Prawo francuskie nawiązało w omawianej kwestii do dosłownego brzmienia źródła rzymskiego. Zarówno notyfikacja jak i jej ekwiwalent w postaci akceptacji, mają charakter wyłącznych przesłanek skuteczności przelewu wobec osób trzecich, nieformalna wiedza dłużnika o cesji nie ma zaś znaczenia prawnego. Ponieważ taka regulacja stwarza możliwość nadużyć ze strony dłużnika na szkodę cesjonariusza, orzecznictwo francuskie interpretuje obecnie art. 1690 c.c. rozszerzająco, jednakże nawet w świetle tez judykatury sama wiedza dłużnika o fakcie przelewu, w braku pewnych szczególnych okoliczności towarzyszących, nie zastępuje nigdy formalnej sygnifikacji lub akceptacji.

Włoski codice civile przewiduje w art. 1265, że mimo braku notyfikacji oraz akceptacji przelewu, stanowiących podobnie jak w prawie francuskim przesłanki skuteczności cesji erga debitorem, świadczenie spełnione przez dłużnika na rzecz cedenta nie będzie miało skutku zwalniającego, jeżeli cessus w chwili spełniania świadczenia o przelewie wiedział. Rozwiązanie to jest bardziej racjonalne w porównaniu $z$ modelem francuskim, gdyż odbiera dłużnikowi możliwość wykorzystania w złej wierze, wynikającej z braku formalnej notyfikacji i akceptacji, nieskuteczności przelewu wobec niego.

Według prawa austriackiego i niemieckiego świadczenie dłużnika spełnione po przelewie do rąk cedenta nie umorzy zobowiązania, a czynność prawna modyfikująca jego treść będzie pozbawiona prawnej skuteczności, jeżeli cessus w chwili świadczenia lub czynności wie o przelewie. Brak tu notyfikacji kwalifikowanej, a jedyną przesłanką uchylającą dobrą wiarę dłużnika jest jego rzeczywista wiedza o cesji.

W świetle art. 167 c.o. dają się wyróżnić aż trzy stany faktyczne, z których zaistnieniem dłużnik nie będzie już mógł skutecznie świadczyć do rąk zbywcy. Obok kwalifikowanej notyfikacji, ochronę bonae fidei debitoris wyłącza rzeczywista wiedza dłużnika o prze-

${ }^{103}$ K. LUIG, op. cit., s. 120-121. 
lewie w chwili spełniania świadczenia lub przedsiębrania czynności, a nadto już sama powinność i możliwość objęcia faktu cesji jego świadomością. Wynika to $\mathrm{z}$ faktu, iż omawiany przepis mówi o świadczeniu spełnionym $\mathrm{w}$ dobrej wierze (... il paie de bonne foi entre les mains du précédant créancier...), a zatem w sytuacji, gdy cessus nie wie oraz nie ma najmniejszych podstaw, by przypuszczać, że przelew nastąpi ${ }^{104}$.

Polski kodeks zobowiązań oraz obecnie obowiązujący kodeks cywilny przewidują w omawianym zakresie dwie przesłanki: samoistną notyfikację oraz rzeczywistą wiedzę dłużnika o przelewie w chwili świadczenia lub dokonywania czynności.

Prawo angielskie oraz amerykańskie stawiają bezwzględny wymóg notyfikacji i nie przewidują jej ekwiwalentów.

Trwałość instytucji denuntiationis, powszechność jej zastosowania jako elementu strukturalnego cesji wierzytelności dowodzi adekwatności unormowania z C. 8,41,3 pr. dla należytego wyważenia kolidujących interesów, dla zabezpieczenia prawidłowego rozkładu ryzyka gospodarczego związanego $\mathrm{z}$ obrotem prawami. Bez względu na to, który pogląd w przedmiocie charakteru cesji rzymskiej uznamy za najlepiej uzasadniony, niezależnie od tego, czy cesjonariusz korzystający z actionis utilis suo nomine był pełnomocnikiem cedenta, współwierzycielem czy też nabywcą pod tytułem szczególnym, niewątpliwe jest, iż w każdej z możliwych konfiguracji, notyfikacji cesyjnej można przypisać określoną rolę w zakresie urzeczywistniania zasad sprawiedliwości wyrównawczej. Fakt, że we współczesnych skomplikowanych systemach prawnych, normujących dalece bardziej złożone stosunki społeczne niż te, dla których potrzeb powstawały instytucje prawa rzymskiego, można odnaleźć podobne konstrukcje i analogiczne motywy, po raz kolejny potwierdza tezę o ponadprzeciętnej intuicji prawnej Rzymian oraz pozwala traktować dorobek rzymskich jurystów jako nie tracący nic ze swej aktualności zbiór prawniczych aksjomatów.

${ }^{104}$ A. SCHNEIDER - H. FICK - F. FICK, op. cit., s. 302; V. RosSEL, op. cit., s. 230-231. 
The Roman Origins of the Notice to DebTor of Assignment

DENUNTIATIO IN C. 8,41,3 PR.

and Selected Contemporary Legal Systems

\section{Summary}

The transferability of relative rights is now commonly admitted as one of the most basic and indispensable foundations of economic turnover. The creditor's right, to which there corresponds a duty of some designated individual, is considered to be first and foremost a fraction of capital, an element of property broadly construed, capable of being alienated. The subjective level of a right, the fact that it belongs to one concrete person against an other, does not constitute its crucial and defining aspect.

The standpoint of classical Roman law was, at least initially, different iurisprudentes used to consider obligatio as a strictly personal legal bond which could not be affected by any subjective transformations. As such a rule did not correspond to commercial needs, there appeared a strong tendency to overcome it by means of legal instruments which to some extent did the work of assignment - novation with a change of subject, based on the Roman delegatio and the appointment of an attorney, authorized by the creditor to sue for the debt in the creditor's name without any liability to account him (procuratio in rem suam). Both devices, forms of Roman, so to say, quasi-cessio, were nothing but palliatives of assignment and as such had many disadvantages. Novation as a contract where the debt owed by the debtor would henceforth be owed to a third party does not preserve the identity of the legal relation - the third party's (quasi-assignee's) right against the obligor is based on the new contract between him and the debtor, while the original debt and correlative creditor's (quasi-assignor's) right cease to exist. The power of attorney however can be revoked at any time by the creditor. Moreover, the quasi-assignor is here still able to sue the debtor personally and thus to deprive the quasi-assignee of the acquired right.

It is disputable whether Roman law ultimately worked out the idea of assignment. Some Romanists claim it never happened. However, according to the alternative view, the methods elaborated by classical jurisprudence to evade unpractical restriction, especially procuratio in rem suam, 
were gradually improved and endowed with properties that finally converted them into a form notionally equivalent to the contemporary understanding of assignment.

As has already been stated, in the light of contemporary legal systems creditor's rights against the debtor can be freely transferred to a third party by a process called assignment without affecting the identity of the legal bond. The debtor is not a party to the transaction and his consent is not necessary to its validity. After a valid assignment is made, the assignee substitutes for the assignor as the person to whom performance must be rendered. There appears a risk that the debtor, unaware of the change, could still treat the assignor to be an obligee and consequently render the performance to him. Such an undue performance in principle does not discharge the obligation and thus the debtor's responsibility to the assignee remains. It therefore follows that although the obligor need not be a party to or assent to the assignment, he should be notified of it so that he knows the person to whom performance is now due.

The notification to the debtor (denuntiatio) has its origins in Codex Iustinianus - C. $8,41,3$ pr. The point of this paper is to outline the influence of the above mentioned source upon some selected contemporary civil law systems, sc. French, Italian, Austrian, German, Swiss and Polish. The Roman concept of denuntiatio appears in all of them as the crucial element of the legal construction of assignment. Furthermore, it seems to be the case that different ways of interpreting C. 8,41,3 postulated by the romanists have been reflected in the manifold of models according to which the contemporary cession is formed by lawmakers of different countries. It has to be underlined that the variety of possible schemes of assignment depends to a large extent on what legal significance is being attached to the denunciation - on whether it is considered to be the condition of validity or efficacy of the transaction between assignor and assignee or whether it serves only as a contrivance to deprive the debtor of the possibility of rendering the performance in favor of the assignor with the effect of discharging the obligation.

The modifications of the Roman norm in the aforesaid legislations fall into three categories: 1) the legal significance of denuntiatio - what is the impact of notification on the legal relation between assignor and assignee, 
2) the technical aspect of notification - what is self-contained denunciation, who is enabled to perform it, what formalities are required for the notice, 3) the equivalents of denunciation - are there any states of affairs that bring about identical effects as self-contained notification, what is the status of the obligor's pure, informal knowledge about the assignment from this point of view.

Some remarks concerning common law systems aim at emphasizing the considerable similarities between them and continental legislations concerning the way in which they regulate the transfer of rights. Here notification plays an analogical role - it has a similar nature, relevance and consequences. 